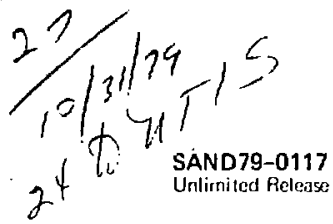

UC. 70

\title{
Gas Generation From Transuranic Waste Degradation: An Interim Assessment
}

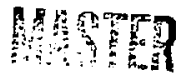

Martin A. Molecke

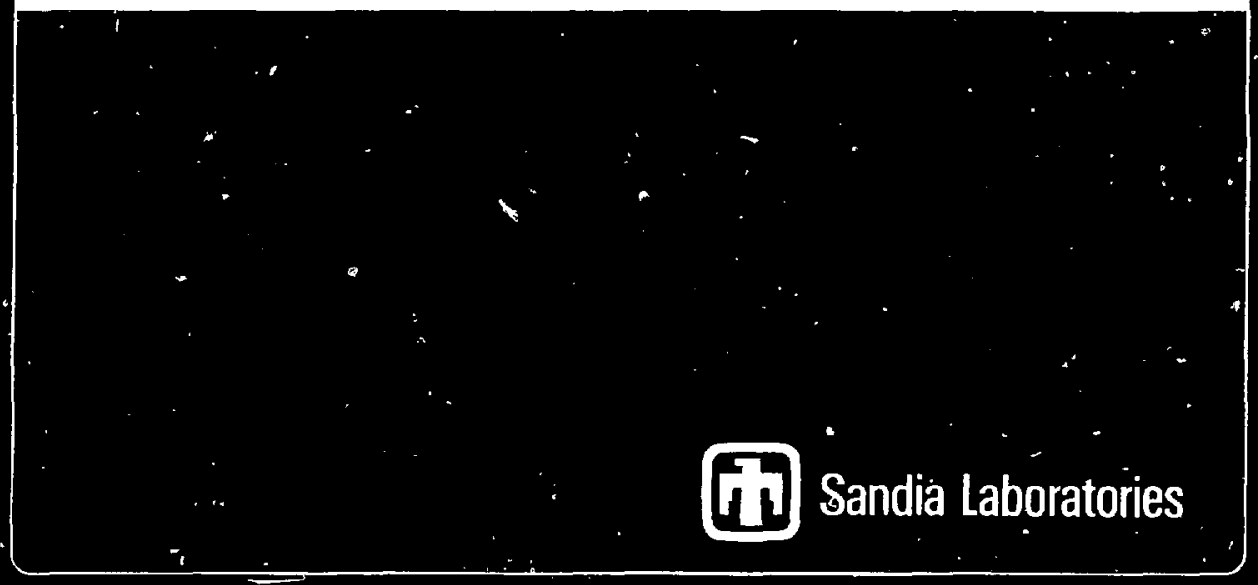

Sf $29000(7.73)$ 
SAND 79-0117

Unlimited Release

Submitted January 1979

Printed october 1979

GAS GEIERATION FROM

TRANSURANIC WASTE DECRADATION:

AN TNTERIM ASSESSMENT*

Martin A. Molecke

Sandi a Laboratories

Nuclear waste Experimental Programs

Division 4512

Alf'iverque, New Mexico 87185

ABSTRACT

A review of all available, applicable data pertaining to gas generation from the degradation of transuranic waste matrix material and packaging is presented. Waste forms are representative of existing defense-related TRU wastes and include cellulosics, plastics, rubbers, concrete, process sludges, and mild steel. Degradation mechanisms studied were radiolysis, thermal, bacterial, and chemical corrosion. Gas generation rates are presented in terms of moles of gas produced per year per drum, and in G(gas) values for radiolytic degradation. Comparison of generation rates is made, as is a discussion of potential short- and long-term concerns. Fechniques for reducing gas generation rates are discussed.

*This work supported by the U. S. Departillent of Energy 


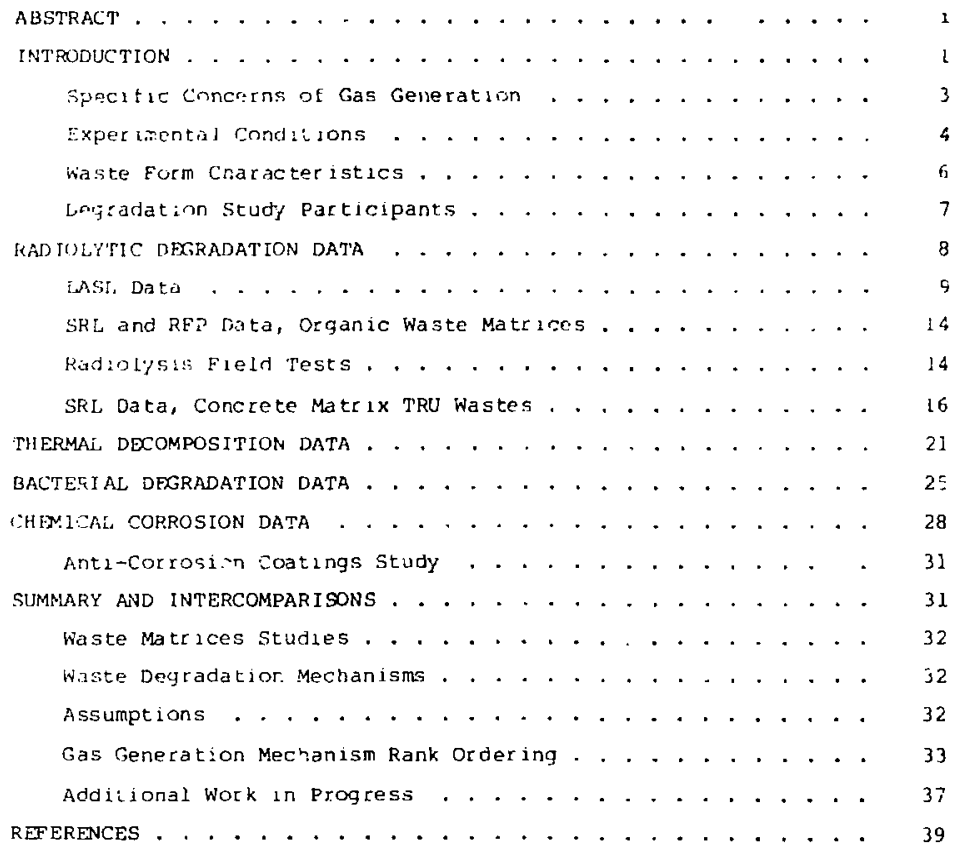


1 Gas Generation Ecom TRi Wastes . . . . . . . . . . . . . . . . 2

2 Pi imary Gas Generation Study Experimenters . . . . . . . . . . 7

3 Existing Radiolytic Degradation Data-organlc Matrices. . . . 10

4 a Radiolysis Data of Concrete-TRU Ash Samples . . . . . . . . . 17

(High A] umina Cement)

4b Radiolysis Data of Concrete-Tru Ash Samples . . . . . . . . 18 (Portland Type 1 Cement)

5a Gas Generation Rates from thermal Degradation . . . . . . . 22

5b Approximate Gas compositions from Thermal Degradation: 700 C. 22

6 Gas Generation Rates Erom Bacterial Degradation . . . . . . 27

7 Intercomparison of Measured Gas Generation Rates . . . . . . . 33

6 Extrapolated Gas Generation for 100 years, per Drum . . . . . 35

9 Theoretical Gas Generation/Drum . . . . . . . . . . . . . . . 35

10 Most Significant Gas Generation studies still in Progress . . 38

\section{LIST OF FIGURES}

1 WIPP TRU Contact Handled Level Temperature. . . . . . . . . . 5

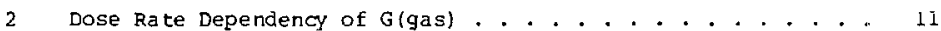

3 Decrease of G(gas) with Time.................. . 11

4 Temperature Dependence of Fadiolysis of Cellulosics . . . . . I3

5 Temperature Dependence of Radiolysis of Polyethylene . . . . . 13

6 Intercomparative Gas Generation Rates . . . . . . . . . . 36 


\title{
GAS GENERATION FROM TRANSUFANIC WASTE DEGRADATION: AN INTERIM ASSESSHENT
}

\author{
INTRODUCT ? ON
}

The generation of gases $f(x)$ the de $z r$ adation of existing and potential lorms of defense-related transuranic waste: has received a conciderable amount of study over the past several years.

Thls area of study, particularty under conditions to be expected for deep geologif termanal solatson, is a major segment ol the Waste Isolation Pilot Plant (NIPP) Transuranic (TRU) Waste Experimental Characterization Program. This program, cunducted by Sandia Laboratorie!; and sponsored by the Deparbnent of Energy, is sumarized elsewhere (i).

Ii is paper contains a comprehensive review and assessment of $a l l$ available, applicable gas Generatıon data tror published repolts p!us unpublished references such as office memoranda, i.hternal laborotory documents, and personal communications. This review iroludes uata on gas generation rates, degradation mechanisins, synergism between mechanisms, gas: compositions, methods $f$ or reducing production rates, and inteccompar isnas between generation modes. Much of the data presented is preliminary and may be modified before the various studies alt completed. This interim ceuisu and assessment was compiled for presentation to the Department of Energy Waste Accept:nce Criteriu Stearing Committee (WACSC) in January 1979. An updated compilation will be presented in July 1979.

The mechanisms of rinu waste matrix and container degradation rosulting in gas generation are summarized in Tabje 1 . Also i isted are the major gases produced in approximate o:der of abundance and signıf

The specific overall study areas for WIPP TRU waste character $1 z a t i o n$ pertaining to gas generation and its significance r.ce listed at the bot:um of Table 1. The Elrst three areas will be disrussed in detail. Data for these endeavors will be coupled integrally with mathematical gas accumulation 
TABLE 1

\section{GAS GENERATION FROM TRU WASTES}

\section{Mechanasms of Waste Degradation, Gas Production:}

1. Radiolysis

2. Thermal and Catalyzed Thermal

3. Chemical corrosion

4. Baccer 1 al

Peimary Gases produced:

$\mathrm{H}_{2}, ? \mathrm{r}, \mathrm{CO}, \mathrm{CH}_{4}, \mathrm{O}_{2}, \mathrm{H}_{2} \mathrm{O}, \mathrm{NO}_{\mathrm{x}}, \mathrm{He}$

\section{Concerns of Gas Generation:}

\section{Long-term: pressurization of repository} breach in containment inteurity

Dperational Phase:

flamable, explosive, toxic concentrations of gases ivel for fire, with initiating event particulate contamination carrier effects on mine design, operation

Areas of WIPP Study:

1. kinetics. species, total extent of gas generation

2. predictıve, analytical modeling of gas generation

3. rechniques, additives for reducing generation rates

4. gas accumulation analysis

5. permeability studies on gas dissipation

6. mine response to gas accumulation

7. WIPP TRU waste acceptance criteria; to limit gas generation 
analyses, measurements of gas permeability il, wIPP rocksalt, and analyses of mine response to gas accumulation (areas 4,5, and 6). These areas are revicwed separately (2).

These studies are in progress at Sandia Laboratories and contractor facilities and are necessary to assess the potential consequences of gas generation from waste degradation on overall repository intagr 1 ty and safety.

\section{Specific Concerns of Gas Generation:}

Concerns over gas generation in the wIPP or other (future) comparable waste repositories can be divided i ito two distinct phases: (?) the short-term or operational phase of the repository, and (2) the long-term phase, after the repository is Eilled, decommissioned, and ultumately sealed. Reference (1) describes these two phases in more detall including all identified concerns.

Long-term concerns are the driving force behind the majority of the WIPP-specific gas generation studies. Long-term potential gas-re:ated

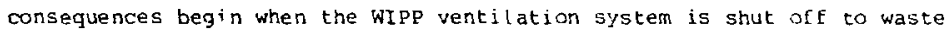
storage rooms just prior to their sealing. Waste storage rooms, backfilled with salt, have some residual void within the salt fill, but corbustibility will no longer be a hazard because of insufficlent oxygen. The major problem 1 ies in eventual pressurization of the remaining vold volume by gases still being produced via waste degradation. Although some modes of degradaition may appear quite slow, significant effects may result over time periods of hundreds of years or longer:

\section{SLOW RATES $X$ LONG TIMES $=$ POTENTIAL PROBLEMS}

In the long term, generated gases are no longer zenoved by ventilation and concentration and potential pressurization could result--particularly if rates of gas dissipation (via formation permeability) are very low. The permeability of gases in WIPP rocksalt has seen messured in the laboratory (2). If the temperature in the TRU waste isolation horizon increases from ambient (about $25^{\circ} \mathrm{C}$ ) due to thermal fie:os arriving from heat generating 
nirf:- $\because 1$ waste or remote-handled TRU wastes stored on other hor izns , i ho isme 1 actlity, waste degradation can be accelerated. The incteasina tomperatures could result in iurther thermal waste degradacion, gas generation, water (sorbed on waste matrlx) vaporization, and higher itoscures, all jggravating the long-tern gas contalnment capacity of the $: a 1$ i $11 \%$.

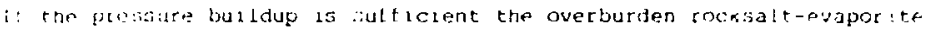

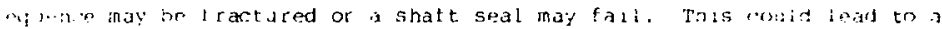

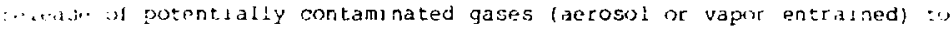

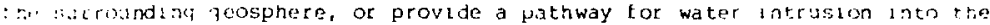

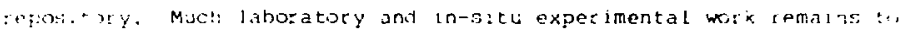
juntity the putental and arediblity of these scenarios.

\section{Experimental Conditions:}

TEMPERALURF: Temperatures of interest for wIPP-spe:illa studins of watse degradation range from $25^{\circ} \mathrm{C}$, the approximate WIPP mine anbient t-mperature du, ing tes operational phase, up to $100^{\circ} \mathrm{C}$, used ror imotest

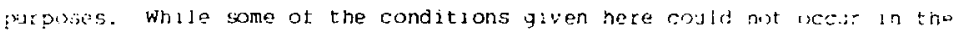
inlpp, conditlons are postulated for more sovere environment.s so that

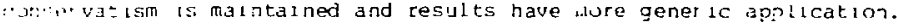

I: heat jeneratiny wastes (e.g., high-level wastes) were conaldered pissent at the lower horizon of the WIPP at a thermal density of $75 \mathrm{~kW} / \mathrm{ar}: \mathrm{re}$ i] 3.5 watts $/ \mathrm{m}^{2}$, , the calculated (3) maximum temperatute obtaned at the Irpoer TRU horizon will be $43^{\circ} \mathrm{C}$. The temperature will rase rapldy from amblent, reach lcs maximuin at approximately 200 years (after sealing), ther. dractease slowly. This temperatuce versus time profile for the wipP scriat-handled TRU waste hor tzon is lblustrated in Flgure?.

An uppe: boundary temperature of $70^{\circ} \mathrm{C}$ was investigated to assess the impact ot coliocation of contact-handled TRU and heat generating waste on tic: same horizon.

Laboratory analyses a:e being conducted at $20^{\circ}$ to $25^{\circ}, 40^{\circ}$, $70^{\circ} \mathrm{C}$, and $100^{\circ} \mathrm{C}$ for overtesting. 
WIPP TRU CH LEVEL TENPERATURE

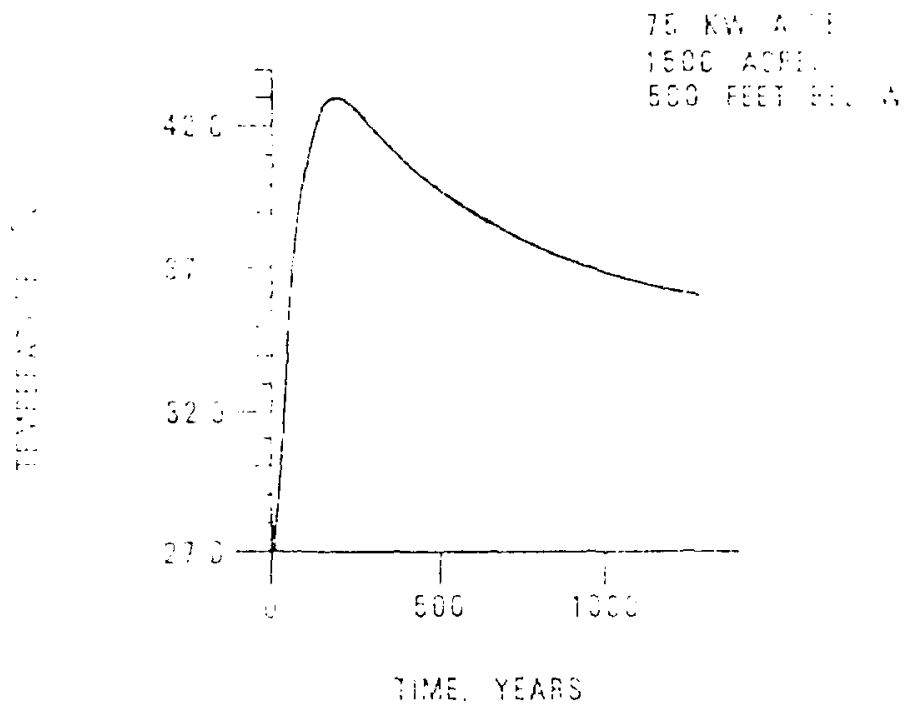

FIGURE । 


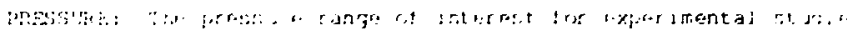

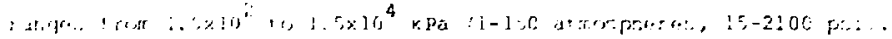

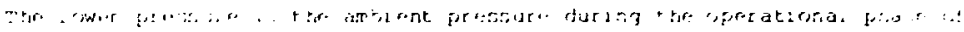

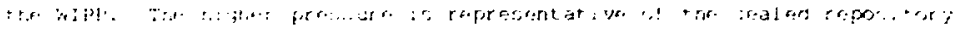

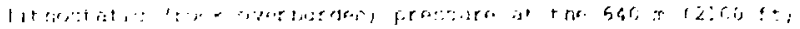

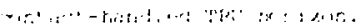

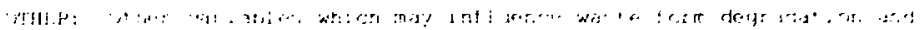
A

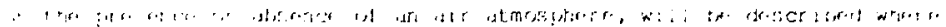
if: $:: 1, \ldots+$

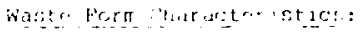

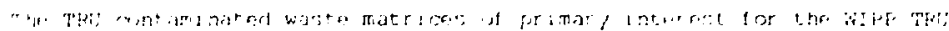

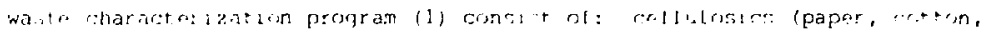

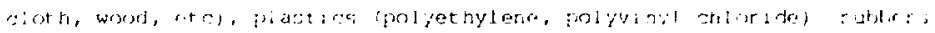

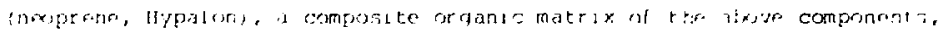

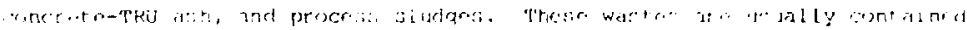

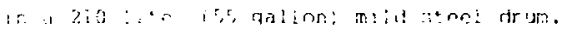

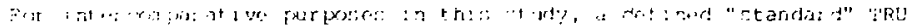

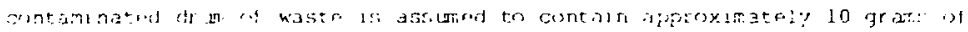

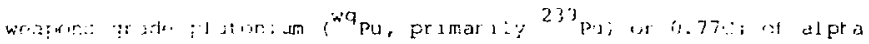

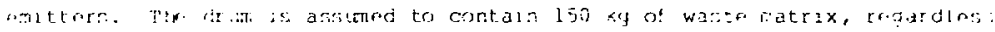

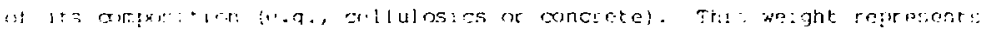

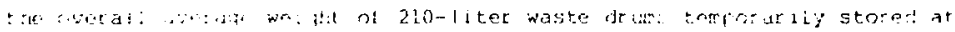

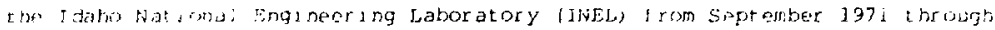

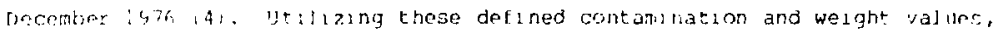

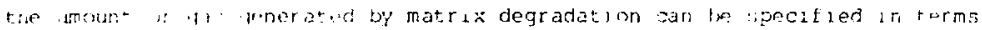
of a "ltandare" alt mutrix wolght hasis.

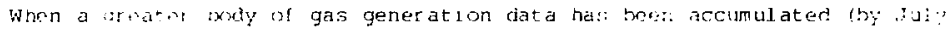

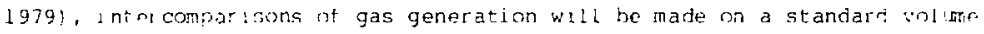

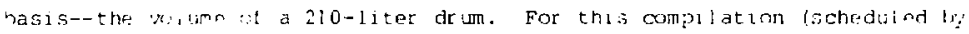
Tuly 199), real: tis values of contamination and matrix weight for exigting

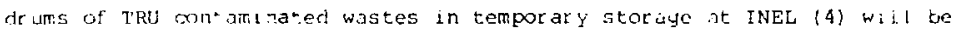
utilized. 


\section{Degradation Study Part 2c1pants:}

The peliary lahoratorles dad experimenters who are onducting TRU waste

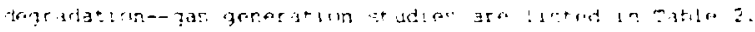

TSR:P I

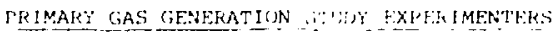

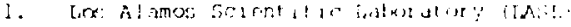

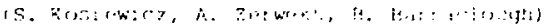

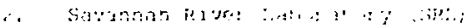

(N. E. BLtion?

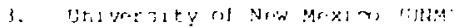

(D) E. Cariwe! ! i

4. Sand:a laborator ! g- 1Sid;

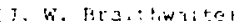

Los Alamos Scientitle laboratories (LASI,), iavannan Rtver bas) iSRl,; and the Rocky Flats plant IRFp! are the only know latoratorles to lad situriad

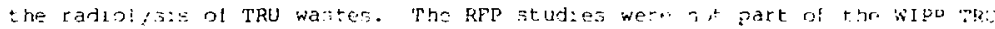
waste characterization prog:ar. LASL 13 mndjetlac the bulk of cutent studies of radiolytis, therma?, and catalyzed thermai degradation ol organir waste mateloor; undel WIPP specill $1 \mathrm{C}$ conditions $(5,5,7,8,9)$. LASL has been conducting similar non-WIPp-related radiolysis studies for over four years $(10,11)$. SRL is conducting radiolytic and thermal degradation studies of concrete encapsliated TRL waste cceicined asgi 113,24 ) and has previousiy studied the radiolytic degradation of organic waste matrices 15 ind and sludges in concrete (16i. The JM Biology Departiont is invest:getlog bacteriai action on srganic waste matrlces which can produce, consume, or transform gaseous products, plus other conseguences of bacterial degradation (17,18). UNM 1s being assisted (under WIPp funding) by LASL (B. Barnhart). The generation of gas from the corrosion of inid stee: TRU waste dr tms is 


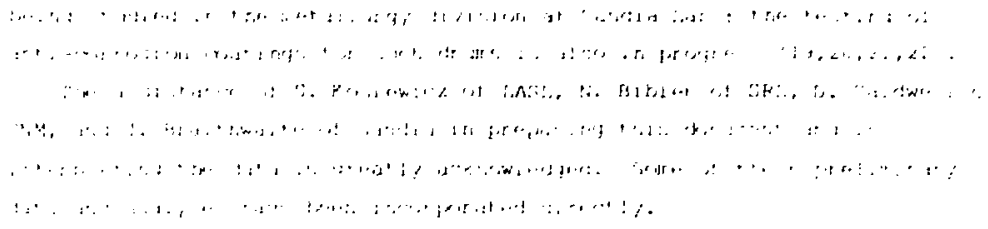

\begin{tabular}{|c|c|c|}
\hline tor exanpase: & w: th $c 1 /$ dr & $0.77 \quad\left(=10 g^{W / g} P_{J}\right)$ \\
\hline$G=1.0$ & yolds & 0.077 moleshyegridr \\
\hline 1.4 & yields & 0.11 moles/youl $\mathrm{drum}$ \\
\hline 3.9 & zieins & 0.14 moles yoar, drum \\
\hline
\end{tabular}




\section{LASL Data:}

T.

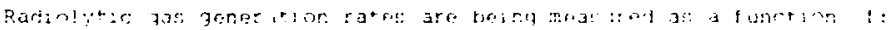

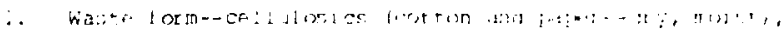

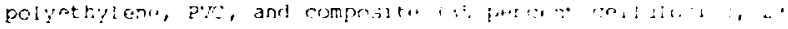

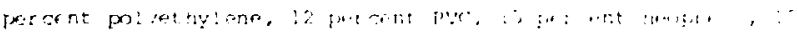

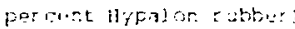

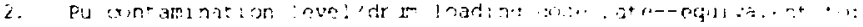
20 to $32,0003 \mathrm{~kg}^{2} 1, \mathrm{dr} \cdot \mathrm{se}, \cdots$

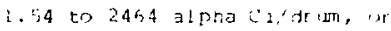

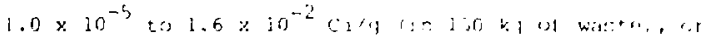

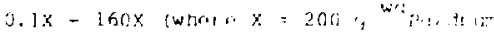

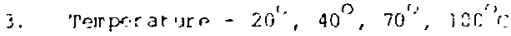

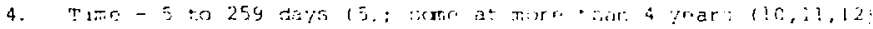

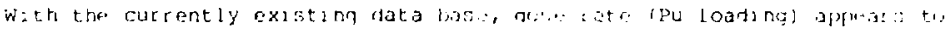

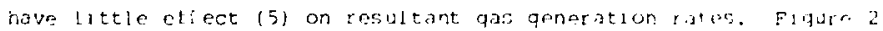

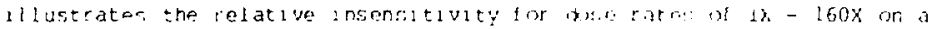

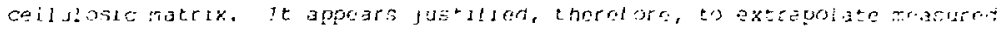

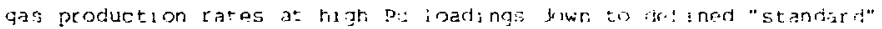
contaninatior loadingr ol 0.77 ciorim.

G(gas) was lound to docreaso as a function of time lintegrated rosara;

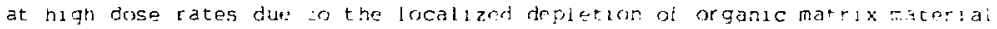

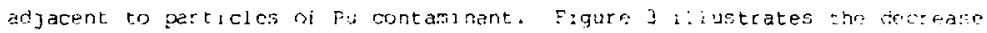

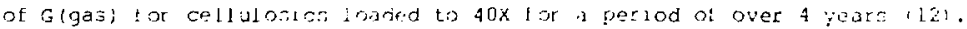

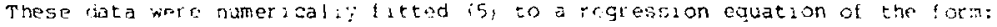

$$
G(\tan )=c_{1} \exp \left(-c_{2} t\right)
$$

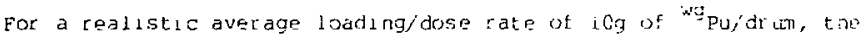
decrease uf $G$ igasj with the wolid be slower by approximately three cide:z of magnitude. For a low dose rate, apparent ly, the offective gas geatiation rate should te guite constant for hundreds of yezrs.

Experiments at LASL, havo been lnitiated (5) in which highly contamlnated cellulosics and polyethyzene ir. test cylinder.s have beer pressurized to approximate:y $] \times 10^{4} \mathrm{kPa}(1500$ psi) with deuter 1 il. These exper $1 \mathrm{ments}$ wi:l 


\section{EXISTIEG HADIULYTIC DEGRADATION DATA}

ORGANIC MATRICES

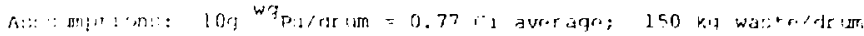

'ASI.: :

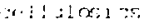

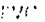

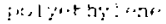

rompate

SPl.: $\quad \therefore: 3: 3$

$\because ! 1,1 ! \infty, 05$

patip t1l:

$x$ tiane

(concrete/TRU ash)

KFF:

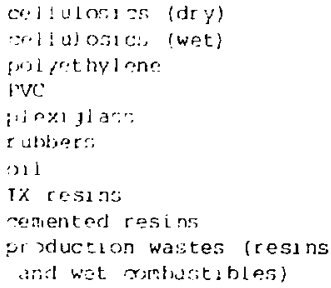

4. pada Decáy:

lte groneration

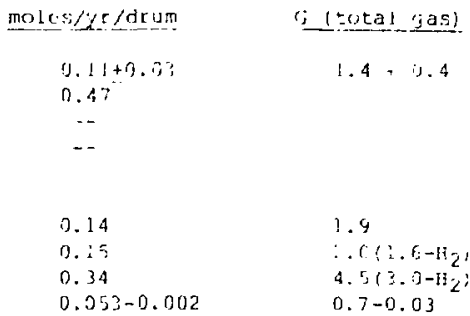

0.05

0.012

0.06

$0.03-0.07$

0.14

0.03

0.24

0.002

0. 16

$0.03-0.16$

(0.53)

(1). 31 .

10.731

(0. $43-0.96)$

(1. 9)

(1). 17)

3. 1 i

(0.1])

$1.5 \times 10^{-6}$ 


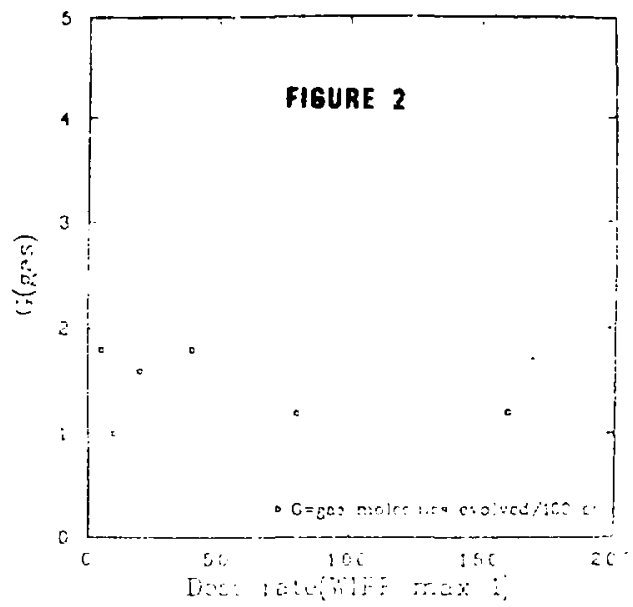

DOSE RATE DEPENDENEY OF G IGAS

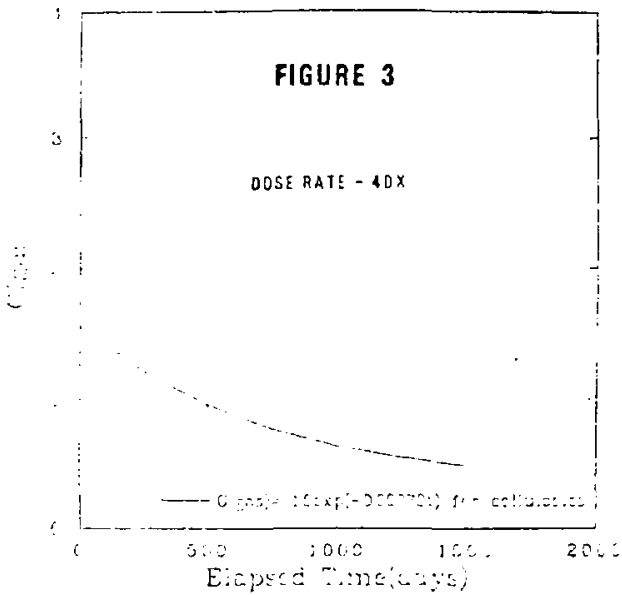

- decrease of G (Gas I with tIME $-11-$ 


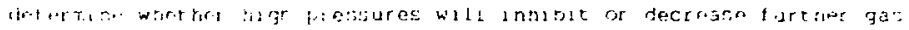

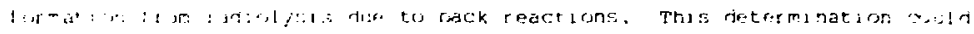

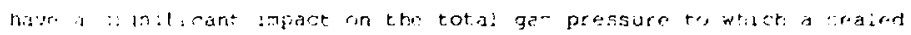

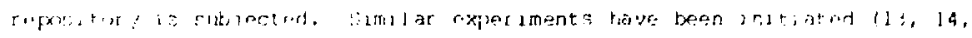

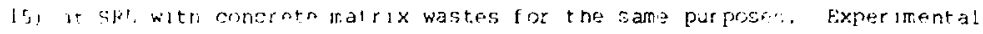

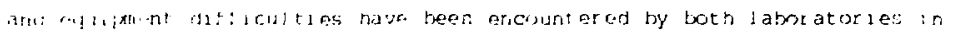

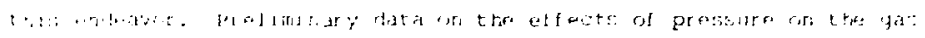

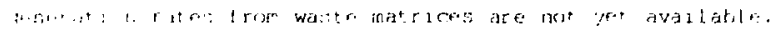

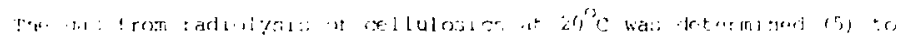

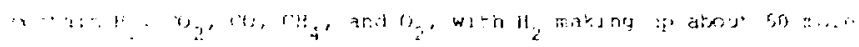

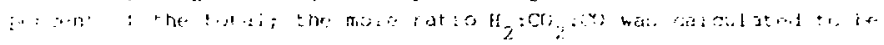

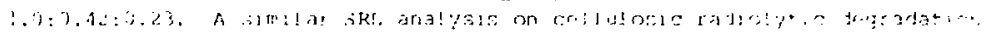

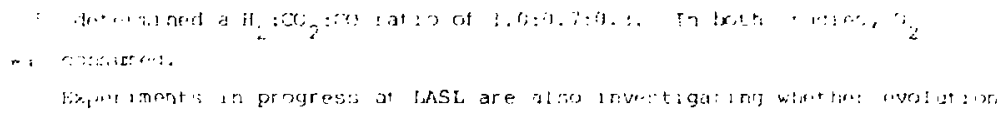

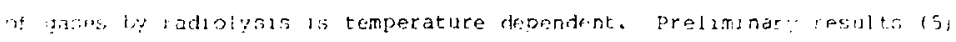

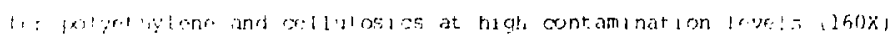

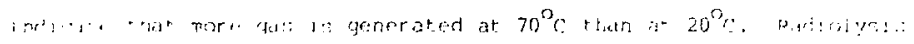

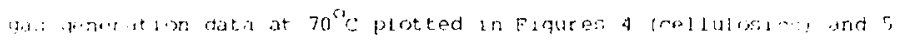

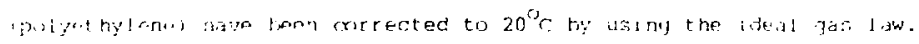

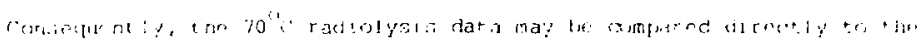

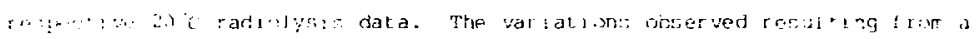

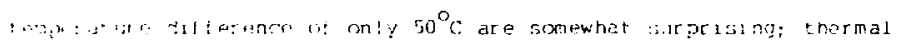

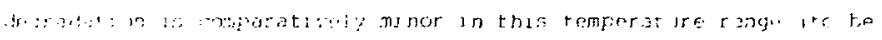

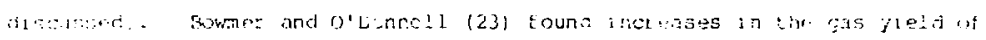

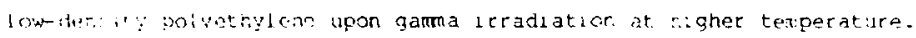

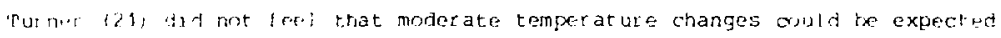

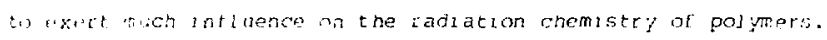

Gar :jonoration measurgments in peoyess (5) at low, reallstic TRU waste

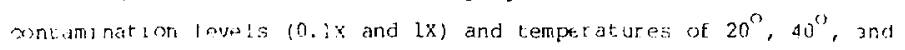

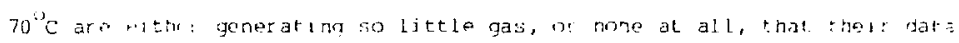
cannot by considered reilable at this time.

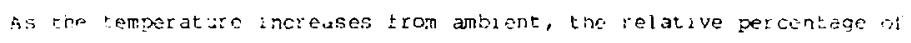
$\mathrm{CO}_{2}$ ant $\mathrm{CO}$ in the generated gas lncreases for oellulosizmatrices. As the cose rat 'ontamination ioading increases, the reiative percentage of i, 


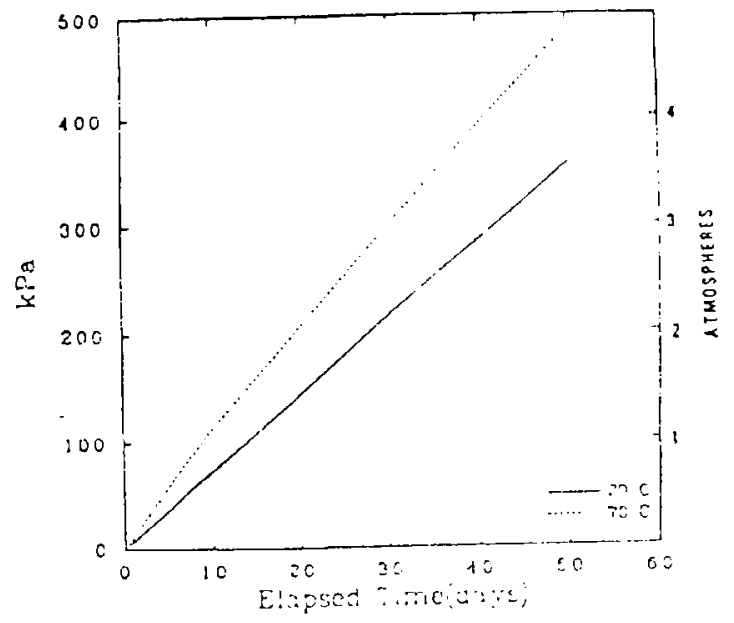

FIGURE 4

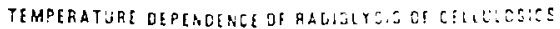

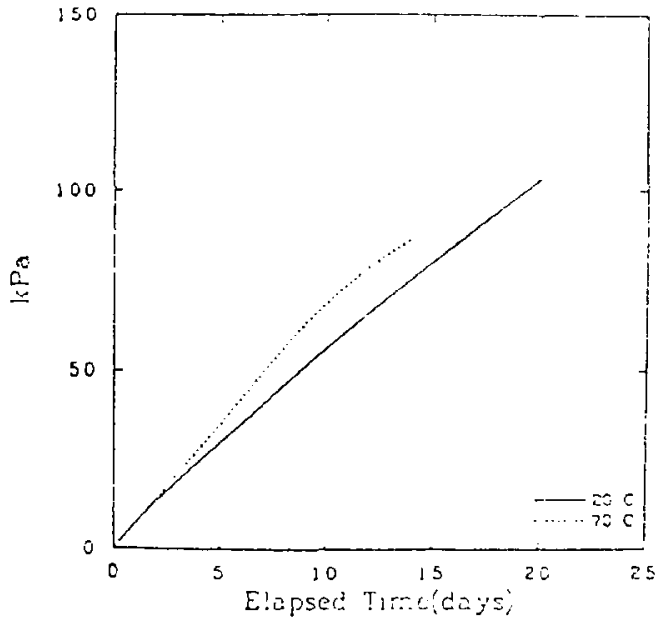

FIGURE 5

TEMPEAATURE DEPENOENEE OF RADIDLYSIS OF POLYETHYLENE 
also lncteases for cellulosic matrices. At concitions expected in the WIPP, temperatures of approymately $40^{\circ} \mathrm{C}$ or less, gases generated by

adiolycurither inal mechanzsms wll consast primarlly of $\mathrm{H}_{2} \mathrm{CO}_{2}$, and co.

SRI and RFP Data, Organic Waste Matrices:

The inSL G(3as) value for ceilulosics, $1.4 \pm 0.4$, compares quits well

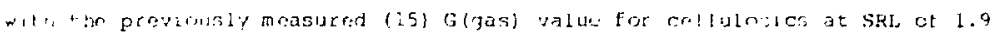
1:3er: ratsis 3.1 .

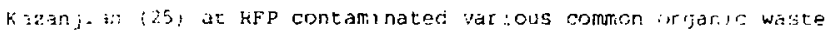

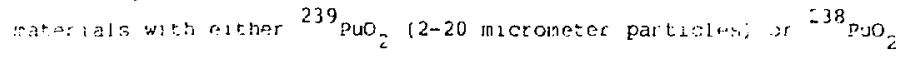

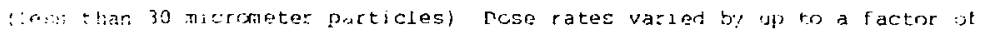

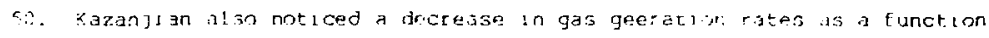
i ine due to localized matiax depletion. Gigasl valur. detormined trom ins: experiments ate presented in Table 3. Di,erepancios betwen the G(gas) Yalues of Kazanjlan and those of LASI and SRL are imeneriately appacent. The RFP Glgas; value tor dry cellulosics is approximately less than one half the LASI, anit SRL $\exists$ lues. RFP aiso obtained lower gas ylelds tor wet cellulosics rhan from try celluiostos; this is contrary lu similar woch pertorned ly

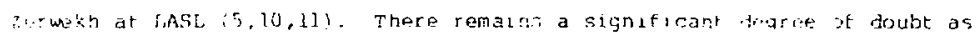
wi the valdity of the kFP data consiter ing these discrepancins between the

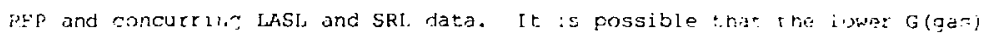

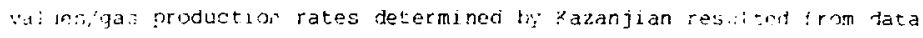
s.alreted after signticant waste depletion had mourred.

Kazanj; an (25) also postuIated that depietion rates we: e dependent on

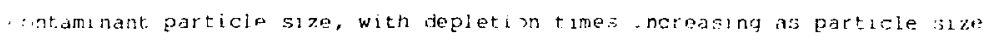
lecreases. Work by Bibler (14) on concretes ames to exactly the opposite ronclusion regacding particle size.

\section{Reiliolysis Field Tests:}

iASL (10,111, SRL $(26)$, and RFP $(27,28)$ have each conducted tleld tests in gases genarated in dr tms of production wastes. Last perindically sampled dr ums of hydrogenous wastes contaminated with ${ }^{238}$ Pu) incated in shallow crenches. No significant internal drum pressurization was detected due to gas diffusion through the standard gaskets; the gaskets are, however, liquid and particulate tıght. Several explosive gas mixtures were detected, soine 
changed to non-explosive but combustible composition aftét a perisd of time. $\mathrm{H}_{2}$ concentrations increased with time and the $\mathrm{O}_{2}$ was depleted as a result of $\mathrm{CO}_{2}$ and (o formation. It was also determined that oxygen (air) could diffuse into the drums while $\mathrm{H}_{2}$ diffused out. Because the possiblitty of an explosible mixture exists, it was stated (10) that all de ums of similar contaminated cellulosics la temporary storage should be considered potentially explosible unt 11 tik yaseous contents have been analyzed and/or replaced with an inert gas. This is a signiflcant consideration when recovering or reprocessing stored wastes.

Other interesting observations were: Rags and paper suffered the most: radiolytic ( $\left.{ }^{238} \mathrm{pu}\right)$ degradation, neoprene tho ieast: $\mathrm{CH}_{4}$ and traces of occasional hydrocarbons with molecular welghts up to about 60 were detected; damp cellulosics undergo more rapid radiolytic degradation than do dry cellulosics (11), possibly due to the additional radiolysis of the sorbed water.

At SRL (26), four typical Savannah River PJant waste dir wis and one waste culvert were monitored for radiogenic gas composition and internal pressurization. Such monitoring covered a period of about 700 days. Drum internal pressures of up to 4 psi were detected; the drum gaskets permitted nydrogen and other gases to diffuse out while oxygen from the air diftused i ward replacing some of the radiolytically depleted oxygen. Hydrogen concentrations in some of the drums arproached 25 percent by volume; $\mathrm{CO}_{2}$ similar ly approached 20 percent by volume.

At RFP $(27,28)$, the hydrogen production rate of several drus of contaminated prodisction wastes was measured. The production wastes consisted of cemented ion exchange resins and cemented resins plus moist combustibles (including plastics and rubbers). "Cemented" ion exchange resin refers to layers of moist, organic ion exchange resins separated by layers of cement powder used to stabilize and soak up some of tre molsture. For the cemented resins alone, a radiolytic $\mathrm{H}_{2}$ generation rate of $5.8 \times$ $10^{-4}$ moles/Ci/day was measured; for a "standard" drimi containing $0.77 \mathrm{Cl}$, this tate is equivalent to 0.16 moles/yr/drum. For waste combinations of cemented resins and moist combustibles, the reported $\mathrm{H}_{2}$ generation rates ranged from 1.1 to $6.1 \times 10^{-4}$ moles/Ci/day, corresponding to $0.03-0.17$ moles/year/drun for a "standard" drum. 


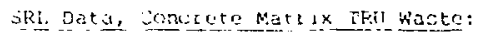

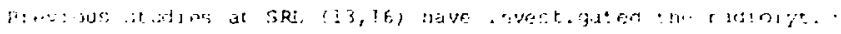

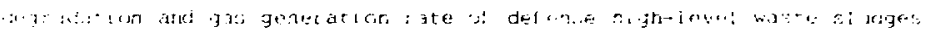

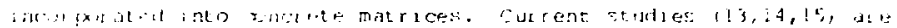

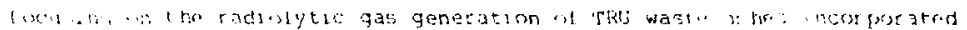

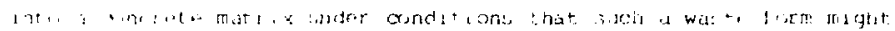

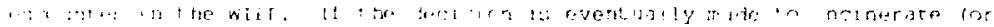

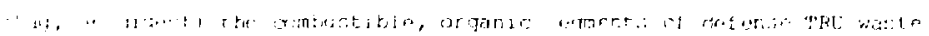

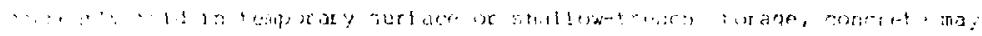

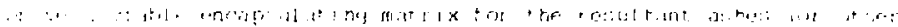

:....

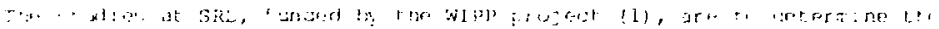

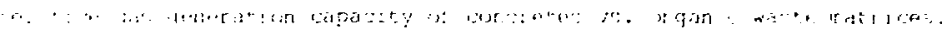

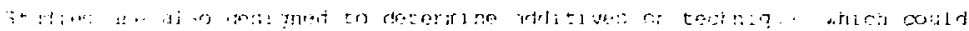

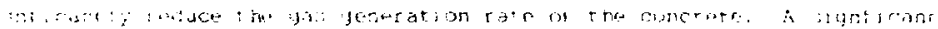

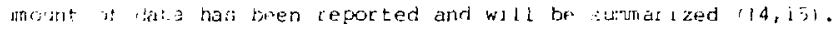

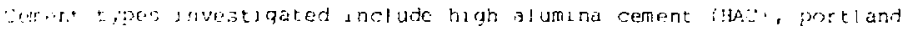

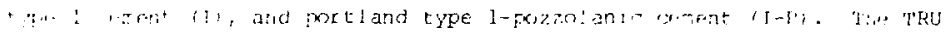

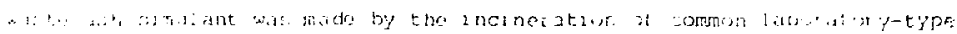

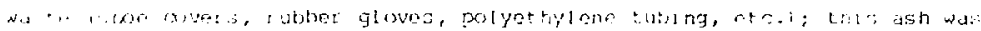

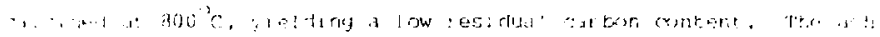

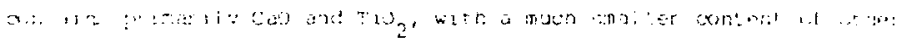

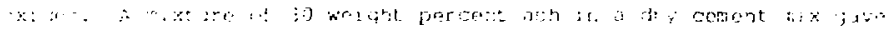

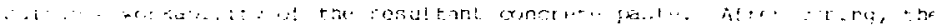

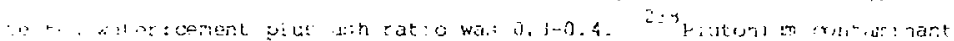

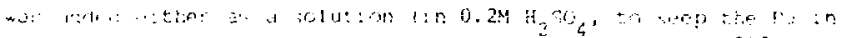

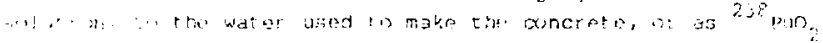

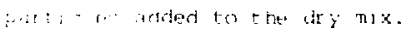

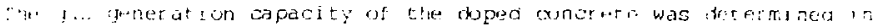

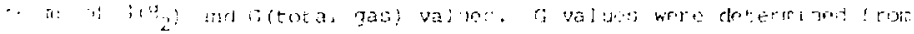

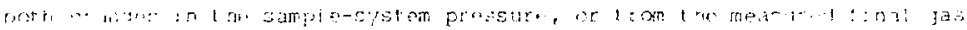

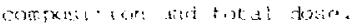

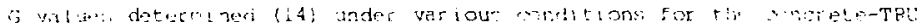

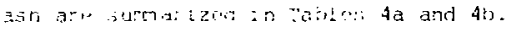


TABLE $4 a$

\section{RADIOLYSIS DATA OF CONCRETE-TRU ASH SAMPLES}

५. gh Alumina Cenent (HAC)

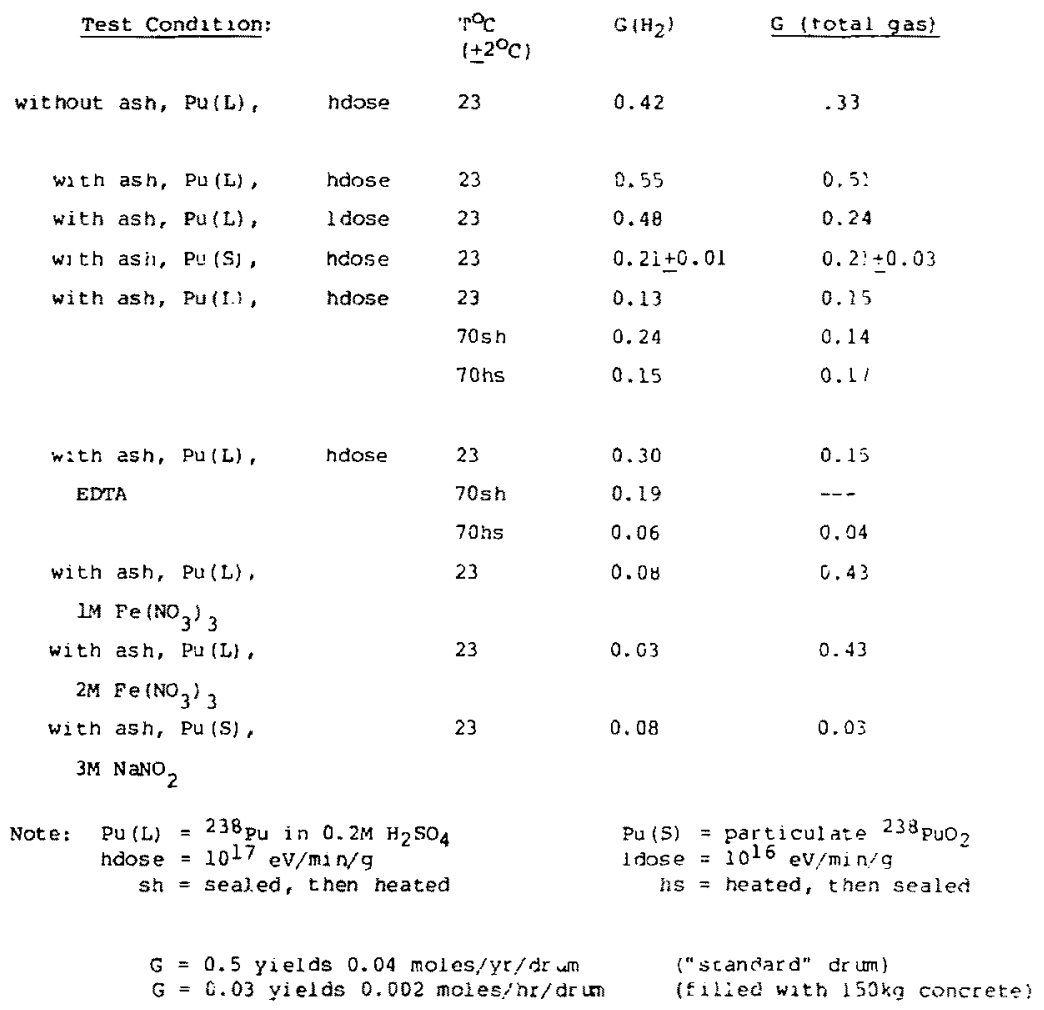


TABLI $4 t$

\section{RADIOLYSIS DATA OF CONCRETE-TRU ASH SAMPLFS}

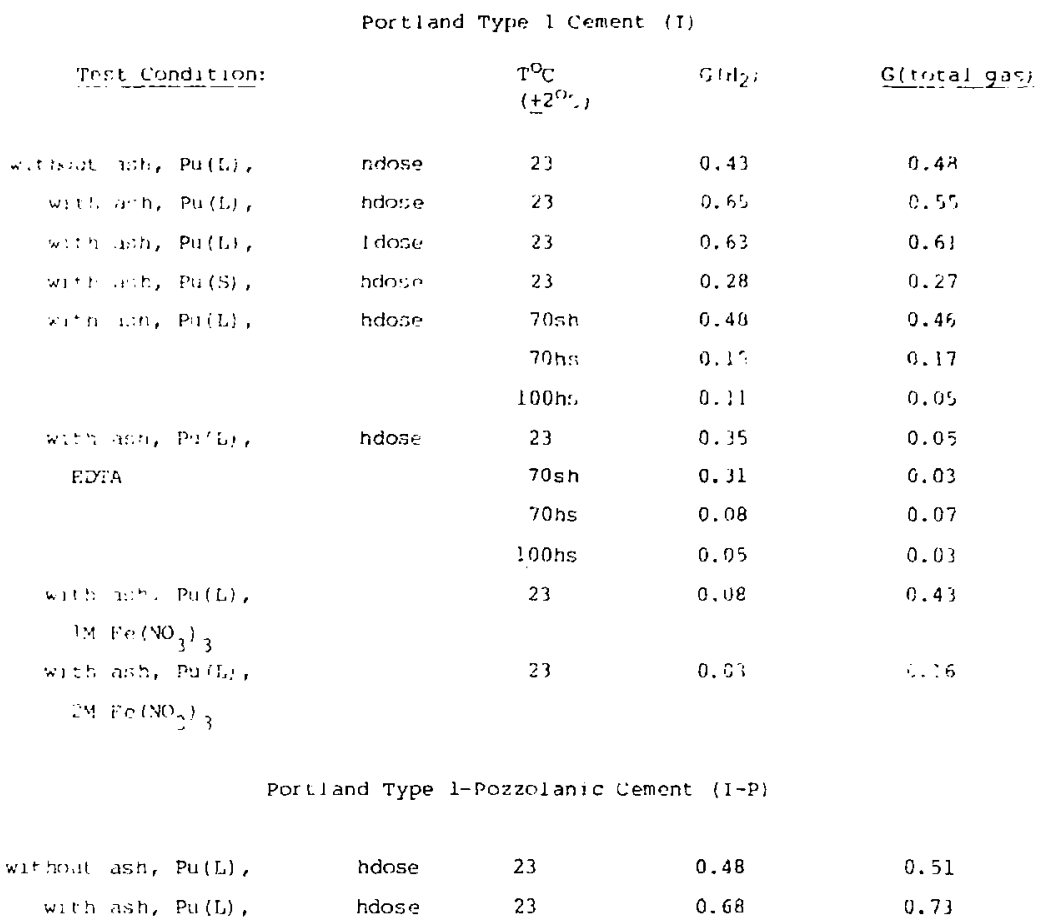


For the HAC, $I$, and $I-P$ contaminated concretes, $i_{2}$ was generally the only gas produced, $\mathrm{O}_{2}$ was depleted, and $\mathrm{N}_{2}$ was unaffected (deviations w11l be described). Hydrogen was not produced when concrete not containing Pu was heated to $70^{\circ}$ and $100^{\circ} \mathrm{C}$.

$G$ (gas) values were higher $(14,16)$ when the concrete contalned the 30 percent ash than when 1 tid not. G(gas) values with and without ash are 0.51 vs. $0.33,0.55$ vs. 0.48 , and 0.73 vs. 0.51 for HAC, I, and $I-P$ matrices, respectively. (The I-P matrix was eliminated after this test.) The Increase of G(gas) with ash present is due to the association of some water with the ash.

A zero-order dose tate dependency was determined $(14,16)$ for $G(7 a s)$ in the concrete matrises, similar to the ion-effect described ear 126 ( 15 ). A maximum drum loading of $200{ }^{{ }^{w}}{ }_{\mathrm{Pu}}$ corcesponds to $3.3 \times 10^{14} \mathrm{eV} / \mathrm{iri} \mathrm{n} / \mathrm{g} 1 \mathrm{n}$ concrete. Dose rates utilized in the sRt study ya led from $10^{16}-10^{17}$ eV/minig of concrete.

The G(gas) value was 1 wer (14) by approxlmately a factor of 2 whi... the ${ }^{238} \mathrm{Pu}$ was added as solid $\mathrm{PuO}_{2}$ particlos tather than being dissolved in $\mathrm{H}_{2} \mathrm{O}$ to make the concrete. G(gas) of Pu(solution) us. Pu(solid) are: 0.51 vs. 0.18 , and 0.55 vs 0.27 for HAC and I concretes, respectively. Jnis zeduction $r e-11$ ted (14) Erom some of the alpha energy being absortued in the $\mathrm{PuO}_{2}$ partic'e rather than in $\mathrm{H}_{2} \mathrm{O}$, yielding $\mathrm{H}_{2}$. In actual waste, $\mathrm{Pu}$ will be added as a solid with the ash and then water will be added to form the concrete. Therefore, tests using the Pu dissolved in acid call be expected to give the highest $\mathrm{G}\left(\mathrm{H}_{2}\right)$ values. It was alsc determined (13) that changing the $\mathrm{pH}$ of added water (contalning contaminant witt an organic complexant agent) from 0.6 to 7 did not signflcantly alter $G\left(H_{2}\right)$. This is consistent with the fact that $G\left(H_{2}\right)$ is andependent of pH for 1 iquid water (29).

For the HAC matrix, $G\left(H_{2}\right)$ was not signficantly affected (14) $0 y$ temperature in the range of $23^{\circ}$ to $70^{\circ} \mathrm{C}$. Indeed G (gas) decreased by a factor of $3-4$ at the higher temperatures of $70^{\circ}$ and $100^{\circ} \mathrm{C}$, resu?ting from the loss of free water from the concrese. This free, or caplliiry, water is not directly involved in the hydration reactions of the cem int. Its ioss does not adversely affect the strength of the cement. Once the free water is out, $\mathrm{G}\left(\mathrm{H}_{2}\right)$ is independent of the temperature. 
The (; gas: value of concrete-TRU ash waste can be sagnflcantly decreasec not. ani: by prineating to drive ofl t ree water, but by the addition of :Ravenging aljnt:; wht ch react with the precursors of $\mathrm{H}_{2}$. Scavenger: Invest ldatri 1;alde nitrate and nitrite lons, and EDTA. The organic

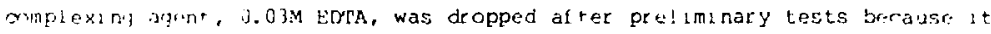
cwid fritentil: $\because$ be responsble tor enhanced actinide mobility if the

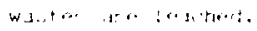

An wximpie "st rcavongeng agent action 1 s:

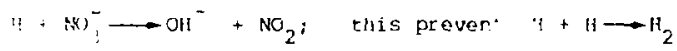

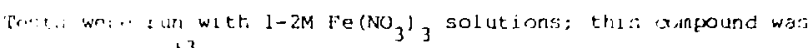

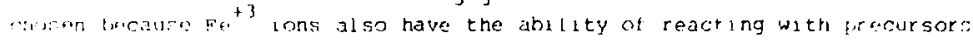

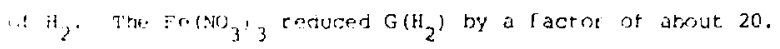
Hiwover, oxpon was produced at a signficant rate, $G\left(0_{2} j=0.31-0.35\right.$; the

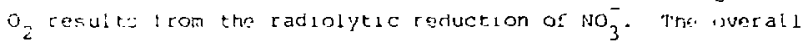

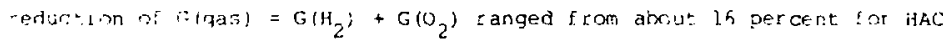
to over zoo percent i or I type concrete.

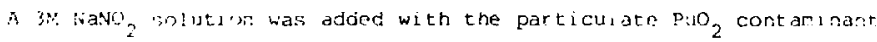
as 2 caveny.r. Nitrite is not stable in acid solution. Nitrite lon: are less offective than nitraze 10 ons for reducing $G\left(\mathrm{H}_{2}\right)$, hut are more éiectip i th raucing the overall G(gas) valde. Fior HAC, the nitrite reducer $G($ gas: $) 1$ rom $0.32+0.03$ down to 0.03 . The oxygen is consumed 2 athe: than produra. with $\mathrm{NO}_{2}$ ordition. However, a small amount of nitrous

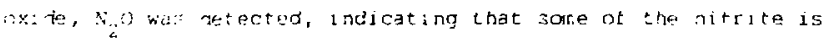
radiolyticaily recuced. Possibly, some $\mathrm{O}_{2}$ is uthlized to oxidize scile of the nitite to nistate.

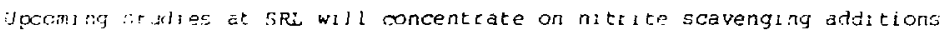
and the oftrc: af high $\mathrm{H}_{2}$ pressures on $\mathrm{G}\left(\mathrm{H}_{2}\right)$. In the past, no pressurs Hepertency was assumed, but the linearlty of pressure increase with time has ween tested $[i f)$ only up to 200 psi. This was due to the difficulties and hazards of wreing with nigh-pressure apparatus in a radioactive contamination jiove box.

The gama radinlysis of concrete containing fission product sludges has al so been studied at SRL $(15,16)$. With gamma radiolysis, $H_{2}$ is the oniy s. gnficant product; $\mathrm{H}_{2}$ reaches a steady-state pressure that increases with 
increasing radiation intensities. Equilibrlum H oressures at reallstic dose rates varzed from 8-28 psi. When nitrate and nitrite lons were present, garma radiclysis also produced oxgen and nitrous oxlde.

Fallure to react a stcady state pressure lat least up to 200 fri: reveals (16) a difterence in mechanism hetween 31 pha and gamma $r$ adiolys: $\vdots$ This results fram a difference in the spatjal distribution of the il ard oH radicals formed by th. two types of radiation. Alpha particles lose ennay in a much smaller volume than gama rays, trus the reaction lntelmediates are formed inuch claser together.

THEFMAL DECOMPOSITIOA DATA.

The thermal degradation of organic TRU wasta mat: $x$ mater 1 ai : :: currently in the process of measurenent at LASL $(5,6,7,8,9)$. Wait matracris under study include: pape:, cotton, and composite (dry and morst). plus polyethylene. Temperatures of interest are $20^{\circ}, 40^{\circ}, 70^{\circ}$, and $100^{\circ} \mathrm{C}$. The $40^{\circ}$ cemperature is probably of most interest for the WIPP TRU waste repository once it is tilied and sealed. A summary of ava:iable. preliminary gas generation rates from thermal waste decomposition ls ilsted In Table 5a. Corresponding approximate neasured gas compositior. at $70^{\circ} \mathrm{C}$ are also listed. Due to low generation rates, gas formation has been otserved $(5,5,7)$ at $100^{\circ} \mathrm{C}$ and $70^{\circ} \mathrm{C}$ onl $y$, Murphy (30) stated that cellulose decomposes even at room temperature at a very siow but tinite rate. The last measured rates of gas generation at $70^{\circ} \mathrm{C}$ for cellulosics (paper, cotton) are several orders of magnitude greater than that predictod by Murphy.

Jtilizing Murphy's relation:

$$
\operatorname{Lng}_{10} Q=16.3-7.4 \times 10^{3} / \mathrm{T} O_{K}
$$

where $Q$ is the gas generation rate $1 \mathrm{n} \mathrm{om}^{3}$ (STP)/year/g. The gas generation rate calculated for $40^{\circ} \mathrm{C} 15$ about a tactor of 100 lejs thari that at $70^{\circ}$. Based on LASL measurnd rates at $70^{\circ} \mathrm{C}$ for cellulosics and polyethylene, this ylelds an approximate gas generation late at $40^{\circ} \mathrm{C}$ of 0.2 moles/yr/dr un $\left(1.3 \times 10^{-5}\right.$ moles/year/gram). Utijizing a simplistic 
TABIE $=\bar{x}$.

\section{GAS GENERATION RATES FKUM THERMAL DEGFADATIIN}

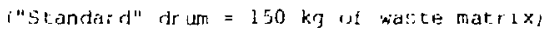

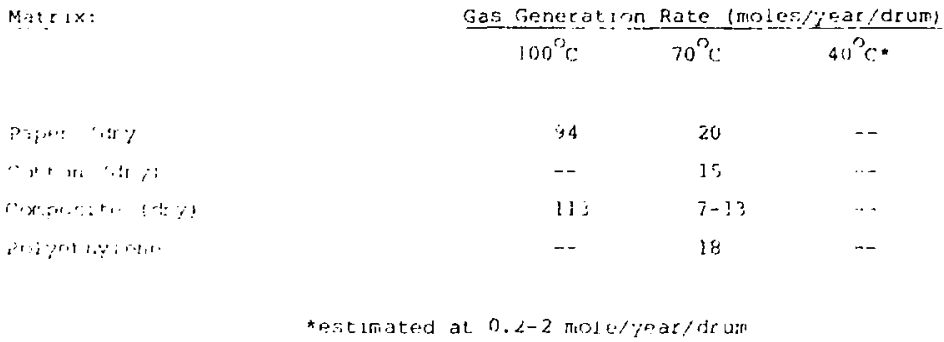


cherristry relationship, that reaction rates double tor every $10^{\circ} \mathrm{C}$ rise $1 \pi$ tempereture, the gas generation rates a: $40^{\circ} \mathrm{C}$ for the organic waste mattices studiel can be estimatedfextrapolated at zpproximately 2 molespyrfiru $11.3 \times 10^{-4}$ moles/yearigram). The nas generat 1 on rate 1s, consequently, bounded at 0.2 to 2 moles/year'drum by the two moturds ot ca!culation.

Muraty (30) also postulateo that thermal decompostion of cellulosics shoud decrease exponentialiy as a function of time. He did nat provide a relationship; asstme $\mathrm{Q}=c_{1} \exp \left(-c_{2}\right)$. No data aro yot availahle tor the tomperature range of primary interest, $40^{\circ}$ to $70^{\circ} \mathrm{C}$. to use tor estimating how much the gas generation ates will decrease, for example, in s00 years. No gas generation data from the degratation ot orgenif liatrices at temparatures of $100^{\circ} \mathrm{C}$ and below huve been cosierved previously, due prinarily to detection technques. Still, nu one had detected, mich lesi expected, gas goneration from thermal degradation at =mperat ures ot $100^{\circ} \mathrm{C}$ or :ess unt 1 the curcent LASL $[$ esults $(5,6,7)$ were prerented. Obrervation of accumulated gases via pressurization lf a more rensltive indication of thermal waste degradation than 1 s weight loss via thermal gravimetric analysis (TGA)--35 usod in earliet studies. Fot example, Tang and bacon (31), in studies of pyrolysis of cellulose fibers at temperatures up to $500^{\circ} \mathrm{C}$, reported that the gaseous decomposition products were water, $60_{2}$, and $C O$, with only physical desorption of water nccurring between $25^{\circ}$ and $150^{\circ} \mathrm{C}$. Clear 1y, the current LASL data $(5,6,7)$ do not corroborate the proposed deconposition mechanism of Tang and Bacon, Vershinski and $P_{1} k$ aev (32) did find, however, that the rate of gas evolution for radxolysis increases sharply at the melting ar softening point of poiyethylene.

Preliminary thermal degradation studies at LASL (8.9) utilizing thermal gravimetic analysis determined threshold decomposition temperatures in air ranging from $175^{\circ}$ to $205^{\circ} \mathrm{C}$ for cllulos $1 \mathrm{cs}$. $150^{\circ}$ to $210^{\circ} \mathrm{C}$ for plastics lexcluding Teflon, and $165^{\circ}$ to $195^{\circ} \mathrm{C}$ for rubber materials comonly found in laboratory waste. previous stuoy at the Battelle Pacific Northwit Laboratory (33) determined the endothermic starting point (Pyrolysis, in nitrogen, utilizang difierentid thermal analysis) for sim 1 ar waste matr ix materials. Polyethylene had the iowest decomposition (melting) temperature of $80^{\circ} \mathrm{C}$; almost all other materials had 


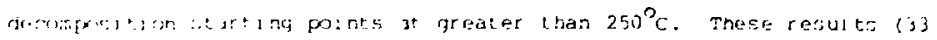

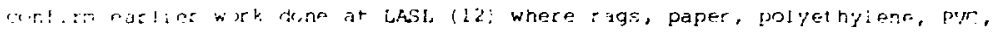

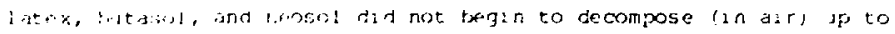

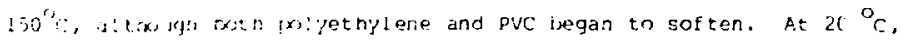

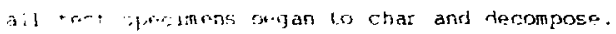

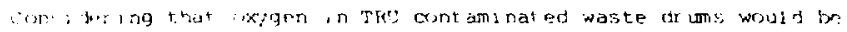

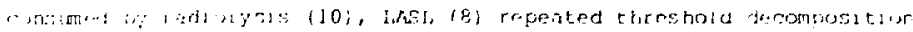

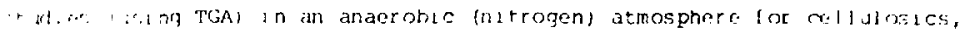

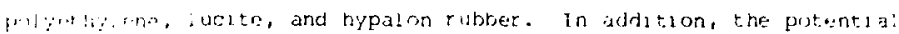

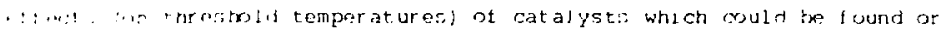
: rowi in ilor: ag drums of TRU watte in a salt mine (the wipp) were

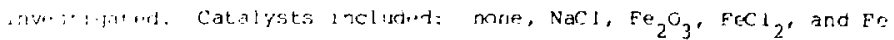

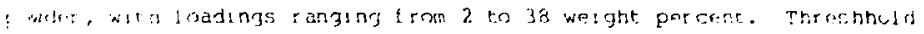

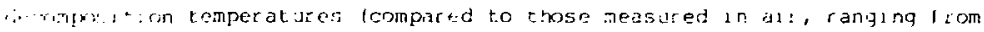

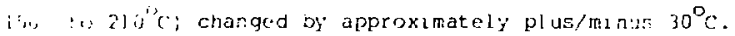

anturning to the prumary objectzve, measurement of gas gereration rates, LAs: :?: nas sacted new tests to svaluate the eflects of possi:ir. inl no

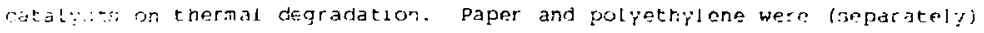

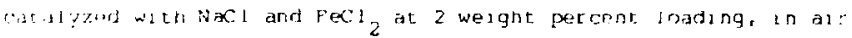
atmopprore, at $40^{\circ} \mathrm{C}$. Gas detections techniques ar teing utilizar, but 1 nout lirent data have been gathered from thest analyses.

ithor pertinent data gathered I rom the Lfist thermal studies inclurse:

1. A11 "dry" cellulosios tested (9) evolvod appoxifitiely 2 weight pergent water (sorbed! when heated from $40^{\circ}$ to $110^{\circ} \mathrm{C}$.

2. Dowater ing of LASE process sludges was cosermined (17) at $25^{\circ}$, $41^{\circ}, 70^{\circ}$, and $100^{\circ} \mathrm{C}$ as a function of tume. These sludges are pr Imas l:y ferric hydroxide precipitant containing about 30 percent aids. Experimental conditions included flowing dr $y$ nitrogen cover gram-31ze samples of sludge contained in a thermobalance. This irtargerent should be somewhat representative oi a (corrosion) ispacted waste drim in a salt repository, with the sait acting as a Aessicant tor released water vapor. Times for 100 percent Hewatraing of the siudge samples ranged from 1 hour at $100^{\circ}$ to 35 hour: at $25^{\circ} \mathrm{C}$. In conclusion, drums contalning sludge waste could be expected to release essentially all their wat ir on a very short (geological) time sca:e due simply to attainment of equiliorium water vapor ptessure. 
3. Cement paste has been used at LASL (5) for immobilization af certain waste matertals. Currently, it comprises the jocond-tanked contributor (by volume) to the LisL waste inventory. Rates ol thermal dewater 1 ng of cement paste at $40^{\circ} \mathrm{C}$ and $100^{\circ} \mathrm{C}$ were perermed for comparison to the process sludge materta:. The cenent paste samples utılized latang from 1374, contalned no lower than 10 weight percent water (as determined by heatirig lu $400^{\circ} \mathrm{C}$ ) and may be considered more similar to concrete than to "paste." From preliminary data, it appuas taat cement paste-concrete is much more dit:icult to dewater than process sludge. cement paste-concrete may rot dewater completely at the cred.iz boundary temperature ol $70^{\circ} \mathrm{C}$ in the iNIPP IRU waste hor a 20 .

The potential tates of water tiermally voidtllized. or that possibly produced by pycolysis but as zet. unmeasdred, are sunrar and be! ow:

a. Dissolution of salt yielding brine pooss or lenses

b. High humidity in mane, pumper out via ventilation rystem dusing werking phase of faclitity

c. Fotential erhanced corcosion of metallac waste canistars, instrunentation, and mining-engineerıng equipment

d. Hydroiysis, hydration of minerals iannyirite, clays, itc.: with potential swelling eftects

e. Leaching or dissolution of waste materials resultin; is the potential water/brine mobilization of radionuclides as trur solutions, colloldal solutions, or as entrained particulate materia!.

\section{BACTERIAL DEGRADATION DATA}

Organic matrix TRU contaminated wastes (unprocessed) will most probably contain bacteria or Eungi prior to isolation in a terminal waste repository. It is assumec that any kind of microorganism may survive and adap to the existing environment, potentially resulting in significant microbial degradation. This could lead to several consequences including gas generation. Overall concerns of microbial degradation 


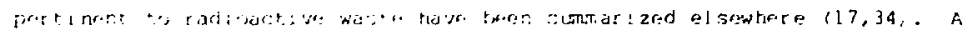

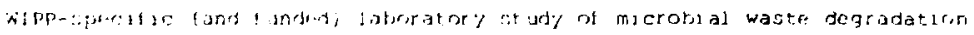

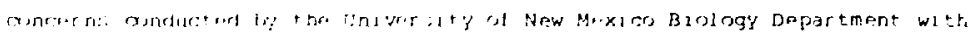

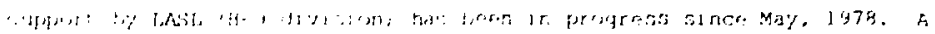

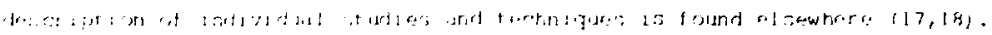

$\left.\therefore 11+42-11_{2} 1\right\}$

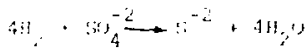

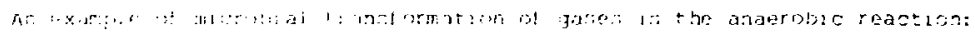

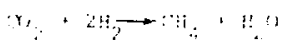

Y:a methanograle bactet la)

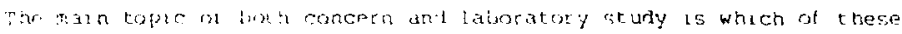
typl: st reaction: w: I Gocur under wipp-specit ic conditions and at what tats. There is no question that $\mathrm{CO}_{2} \mathrm{w}_{11}$ be produced regardiess of the

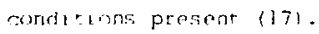

The selimi nal'y ga: generation data mearured at UNM (18) are sumar ired in Tabla 6. Inttaliy, oniy tho oxyen concentration lair atmosphere and anaerobisi, =mperature $: 25^{\circ}, 43^{\circ}, 50^{\circ}, 60^{\circ}, 70^{\circ} \mathrm{C}$ ), and organic

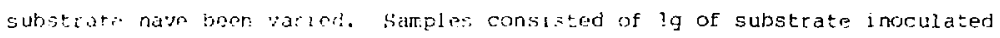
wh 20rs of sol: roxture containg bacteria. Subsequently, either 10 or 1000 micrsiters of phosphate tiuffer, $0.01 \mathrm{~m}, \mathrm{pH} ? .0$, were added to each sample wal only results obtained with the $1000 \mathrm{microliter}$ of buffer addition are presented in Table 6; Insufflcient data hare been obtained with the 10 microliter addition. 
TABLE. $F$,

\section{PRELIMINARY GAS GENERATION RATES FROM BACTERIAL DEGRADATION}

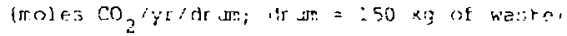

yatro:

LASL Gripos: te

apralt

$$
7
$$

$2 r^{n}$

$40^{\circ}$

3i)

$t: 0^{n}$

$75^{\circ}$

$25^{\circ}$
Aler Di:

2.5

22

35

$: 5$

$\therefore .4$

2.1
0.3

sandis in:

3.6

5,9

74

i

0.4 
Gai promeded $r_{y}$ iactertal action was andlyzed with an automated gas chromatoyrepr witr: i trarmal conductivity detector. Detection sensitivity fur the potantial fanors of interest, $\mathrm{H}_{2}, \mathrm{CO}_{2}, \mathrm{CO}, \mathrm{SH}_{4}, \mathrm{H}_{2} ; \mathrm{SO}_{2}$,

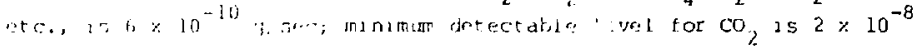

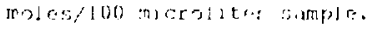

The only thefer ads ritgeted (13) as a degradation product of LASL

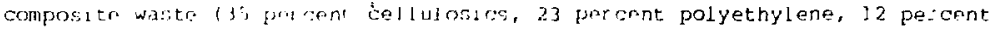
PVC, and 0 ; percent of visious rubberaj was $\mathrm{CO}_{2}$. From the preliminary

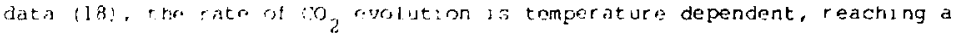

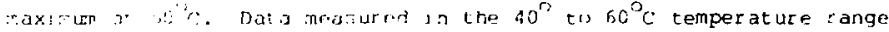

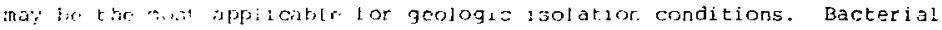

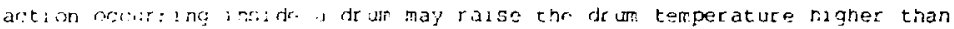
tho thing artilent =erperaturn.

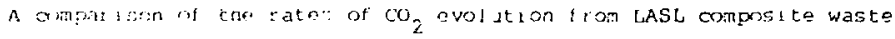
with that I rom carboxymethyl-cellulose (not presented) indicates sme corcalition. Thus suggest:; (18) that the cellulose omponent ot the compost te waste ls thr substrate utilizad for $\mathrm{CO}_{2}$ evolution. A series of aamples crintanini componite waste minus the cellulosic component will be

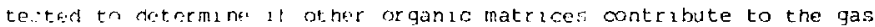
generation.

Exper lmenta] terholques are being modit ded and an expanded test matr $2 x$ utilized to loclud variaruns in pil and salunty, and to determine gas production rate as a tunction of time. Data should be obtained prior to october :979. Thcre dala should betier reflect long-term microbial activityin organte the waste matrices in hedded salt geologic lsolation. Data now available und cate that bacterlal degradation yieluing gas generatuon is quite rignaflcant and must be taken into account.

CHEMTCAL CORROSION DATA

The generat loi of $\mathrm{H}_{2}$ gas from the corcos.on of the mild steel alloy used in TRU waste contalners, 2101 (55 gallon) drums, is the only long-term chemical degradation mecnan $25 m$ of slgnificance yielding gaseous reaction products.

The aqueous corrosion race of most mild (carbon) steels, e.g. 1018 steel, is controlled by diffusion of dissolved oxygen to the steel surtace. This is followed by the cathodic reduction of oxygen (19): 


$$
\text { a) } \mathrm{O}_{2}+2 \mathrm{H}_{2} \mathrm{O}+4 \mathrm{e}^{-}-4 \mathrm{OH}^{-}
$$

If $\mathrm{O}_{2}$ :s kopt : rom the metal surface, then the cathodic reaction is the reduction of $\mathrm{H}_{2} \mathrm{O}$ in neutral solutions or nydrogen ions in acid sol tion, ;ielsing gajerous $\mathrm{H}_{2}$ :

$$
\begin{aligned}
& \text { b) } 2 \mathrm{H}_{2} \mathrm{O}+2 e^{-} \rightarrow \mathrm{H}_{2}+2 \mathrm{OH}^{-} \text {(neutial) } \\
& \Rightarrow 2 \mathrm{H}^{+}+2 \mathrm{0}^{-} \rightarrow \mathrm{H}_{2} \text { (acd d) }
\end{aligned}
$$

The anodic reaction is the oxidation and dissolutior of Fe:

$$
\text { (1) } \mathrm{Pe} \rightarrow \mathrm{Fe}^{+2}+2 \mathrm{e}^{-}
$$

Reaction a) always proceeds preferentially over teaction bi when oxygen is present ans: is 10 to 100 times faster.

For milt steel, the aqueous corrosion rate ( $\mathrm{n}$ aerated water) at $25^{\circ} \mathrm{C}$ would be approximately $0.3 \mathrm{~mm} / \mathrm{yr}$ for the first year, fropping of t to 0.05 to $0.08 \mathrm{mra} / \mathrm{yr}$ thereafter. This rate doubles for each $30^{\circ} \mathrm{C}$ rise in temperature, With no oxygen present, the agueous corcosion rate woulc: ahout $0.005 \mathrm{~mm} / \mathrm{yr}$, with this rate doubling with each increase of $10^{\circ} \mathrm{C}$ Bralthwate (20) measured the rate of corrosion of $1018 \mathrm{~m} l$ la steei in 1 nundatod saturated $\mathrm{NaCl}$ brine at $25^{\circ} \mathrm{C}$ by measuring the quantity of nydrogen produced or oxygen consuned. These corrosion rates and gaseous quantities are:

$$
\begin{aligned}
\text { aerated }- & 0.05 \mathrm{~mm} / \mathrm{yr} \text { (in oxygenated hrine) } \\
& 5.4 \mathrm{moles} \mathrm{O}_{2} / \mathrm{m}^{2} \text { year consumed } \\
\text { deaerated }- & 0.003 \mathrm{~mm} / \mathrm{yr} \text { ( } 1 \mathrm{n} \text { deaerated brine) } \\
& 0.5 \mathrm{moles} \mathrm{H}_{2} / \mathrm{m}^{2} \text { year produced }
\end{aligned}
$$

These rates are quite similar to the corresponding. irrosion rates in water. 
Since a 210 . Ar un has a total surtace area (1nside and $0: 1 t)$ of $4 \mathrm{~m}^{2}$, thr appropriate gas generation/consumption rates, assuming inundation, ace:

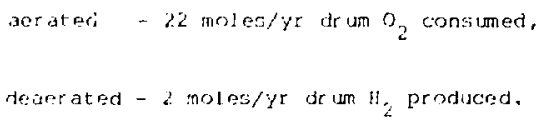

Detalled corrusion data for other alloys, at temperatures up to $250^{\circ} \mathrm{C}$, and under various enviconmental conditions pertinent to a salt high-level waste ripository are summarized elsewhere (36).

For the WIPP environment, the following points about hylrogen gas generat 1 on can be made (2I):

1. Any oxjgen present will substantially reduce the amount of hydrogen produced.

2. Overall, if the oxygen is depleted and water is present, a total of 672 moles of $H_{2}$ can theoretically be produced from the complete corrosion of a $2101 \mathrm{drum}$.

3. No hydragen will be produced if moisture does not contact the steel drum (dry salt); the only reaction, which will be extremely slow, is:

$$
4 \mathrm{Fe}+3 \mathrm{O}_{2}-2 \mathrm{Fe}_{2} \mathrm{O}_{3}
$$




\section{Ant1-Corrosion Coating Study:}

The use of coatıngs to 5 lgnalicantly reduce corrosion of TRU waste metal drums, and potential resulting gas generation for consumptioni, $1 \mathrm{~s}$ also being studied at Sandia Lahoratories (20). Antl-corrosion coatings under study are limited to various classes of paint, primarily because of recognized cost and ease of application considerations. The driving torce betind this particular study is the rovention of significant corcosion on waste ontalners durjng the limited initial storage period (estimated at 5 to 25 years) when such waste might be required tu be retrievable $(1)$. Accelerated aging testing of selrcted cotinms (on a $1018 \mathrm{~m} 1 \mathrm{~d}$ zteel substratel utilize an alternate imetsion in brine then air drying procedure. ahis type of exposure was sevelc and led to localized tal lure of all the palnts evaluated (22). The time to fallure is a measure of the durability ot the paints and decreased in the tollowing order: coal tar epoxy, chlorinated rubber, polyamide epoxy, acrylic enamel, lacguer (22). Acrylic enane? is the coating curzently used on waste dr uns stored at the Transuranic Storage hrea pads at the Idaho National Engineering Laboratory. Uther cotangs previnusiy evaluated (20, ancluded vinyl latex, silicone rubber, polyester resin, asphalt epoxy, and polylmide dip. The alternato immer:lor test results $(22)$ zhould only be used for the rank urdering of the coatzng durability and bo no: indicate that the coatangs will fall uncer more reailstic conditions. For this reason, future fvaluations will be conducted un more benign environments (salt fog, high humidity, crushed salt, otc.; : n order to assess tne long-term durability of these candidate paint.s.

\section{SUMMARY AND INTERCOMPART SONS}

The generation of gases $f$ rom the degradation of existing and potentia! forms of defense-related transuranic (TRU) contaminated wastes has received a considerable anount of attention over the past several years. This area of study, particulat $1 y$ under environmental condiwons to be expected for deep geologic terminal isolation, is a major segment of the waste Isolation Plot Plant Transuranic Waste Experimental Characterization Program (1). A comprehensive zeview and asséssnent of all available, applicable waste degradation-gas generation data is presenced herein. 
Waste Malrices Studies:

CELLULOSICS

PLASTICA

RUBBERS

COMPOS ITE labove or qanics;

CONCRETÉJ

MILD STEEL

Gas generation rates of the above matrlces have been measured in terms of moles gas/year/drum of waste. The following waste degradation mechanisins have benn studied:

Waste Degradation Mecharisisms:

RADIOLYTIC

THERMAL CATALYZED THERMAL

BACTERIAL

CHFMICAL OORROSION

ALPHA DECAY (He Generation)

Synergistic ettects between temperature (in the range of $20^{\circ}$ to $70^{\circ} \mathrm{C}$, and $100^{\circ} \mathrm{C}$, for overtesting) and the other mechanisms have also been studied.

Assumptions are made regarding a "standard" reference waste form and contaner so that intercomparisons between different degradation mode results can be made. These are:

\section{Assumptions:}

1. "Standard" Drim Contains 0.77 alpha Ci or $10 \mathrm{~g}{ }^{\text {wg }} \mathrm{Pu} / \mathrm{dr}$ um

2. "Standard" Drum Contains $150 \mathrm{~kg}$ of Organic Matrix Waste

3. Standard $210 \perp$ Drum : wt. $=25 \mathrm{~kg}$, surface area $=4 \mathrm{~m}^{2}$

An intercomparison of total gas generation rates measured for vatious mechanisms and several matrices is presented in Table 7 , in terms of moles gas/yr/standard drun.

From the measured total gas generation rates in Table 7 , it can be seen that the unly insignificant generation made is alpha decay yielding He. Representative, realistic conditions to be expected in a repository include a temperature range of about $25-40^{\circ} \mathrm{C}$; a very small amount of water present 
TABLE 7

\section{INTERCOMPARISON OF MEASURED GAS GENERATION RATES}

$\{0.77 \mathrm{Cl}, 150 \mathrm{~kg}$ matr $1 \mathrm{x}$, per drum)

\begin{tabular}{|c|c|c|c|}
\hline Mechanism: & Mater 1a1: & Total Tas Rate: & Coments: \\
\hline & & (moles/yridr un) & \\
\hline \multirow[t]{3}{*}{ RADIOLYSIS } & Cellu.osles & $0.13+0.03$ & LASL, SPI \\
\hline & PUC & 0.47 & LASL \\
\hline & HAC Concrete/Ash & $0.04-0.002$ & SRL \\
\hline \multirow[t]{6}{*}{ THERMAL } & Cellulosics & $(0.2-2)$ & $40^{\circ}, \operatorname{cat} 2$. \\
\hline & Cellulosics & $15-20$ & $70^{\circ}$, LASE \\
\hline & Composite & $(0.2-2)$ & $40^{\circ},=31 \mathrm{c}$ \\
\hline & Composite & $7-13$ & $70^{\circ}$, EASL \\
\hline & Polyethylene & $10.2-2$ & $40^{\circ}$, calc. \\
\hline & Polyethylene & 18 & $70^{\circ}$, LASL \\
\hline
\end{tabular}

SACTERIAL

CORROSION

ALPHA DECAY
Composite

Composite

composi e

Mild steel

He Generation
Aerobic//Anderobic

$\begin{array}{ll}2.6 / / 3.6 & 25^{\circ}, \text { UNM } \\ 22 / / 5.0 & 40^{\circ}, \text { UNM } \\ 36 / / 94 & 50^{\circ}, \text { UNM }\end{array}$

2.0

deaerate: br lne inunclat:on, SLA 
in drums, from molst cellulosics primarily: and, an aerobic in-drum environment changlng to anaerobic. Under such conditions, we can rank che gas generation mechanisms in or der ot signficance as follons:

\section{Gas Generat:on Mechanısm Rank Urder ing:}

1. BACTERIAI

2. THERMAT.

3. RADTOLYSIS

4. CORROSION idry CONCitions!

In order to gut the above nechanisms 1 nto perspective, the total amount of gas generated per dria of existing organic matrix waste for a 100-year degradation $x=1$ od 13 shown in Table 8 and Figure 6 , and is based on extrapolation of initial observed rates. The maximum and mimim amounts of gas generated are indicated and reasons for such will be described. For comparative purposes only, the theoreticai maxinum number of gas moles generated-- if all waste form materials and container were degraded into gascous species in an air atmosphere by a combination of probably incredible mechanisms (i.e., ingh temperature combustion)--is listed in Table 9.

Raciolytic degradation of organic materials yielding gas has been found ro decrease as a tunction of time due to snatix depletion at high rinso rates. However, for a low dose rate of $0.77 \mathrm{Ci} / \mathrm{dr}$ um, the rate of radiolysis should presumabiy renain onnstant fur 100 years. IE localized depletion should occur, int unate contaminant-organic matrix contact with Eresh matrix materials ould recur if TRU waste drums are eventually crushed by the lithor tatic pressuce in a sealed reposicory. The maximum and minimum moles of gas generated by : adiolys:s for organics are therefore specified as I dentical.

If organic matrix TKu contaminated wastes are processed (incinerated, slagged, digested, etc.) ... th the byproducts (e.g. ashes) immobilized in a non-organic matrix, the gas genertion rate can be reduced by approximately two orders of magnicude (with concrete) to a celatively insignficant value. The minimum gas value listed in Table 8 for concrete encapsulated TRU ash can be achieved by preheating the concrete matrix during processing to drive oft the free water. It can also be achieved by adding scavenging agents such as $\mathrm{NaNO}_{2}$ to the concrete mix to react with the radiolytic precursor products which form hydrogen. 
TABLE 8

\section{EXTRAPOLATED GAS GENERA"ION FOR 100 YEARS, PEZ DRUM}

(150 kg mat $\mathrm{k} \times \mathrm{x}$ )

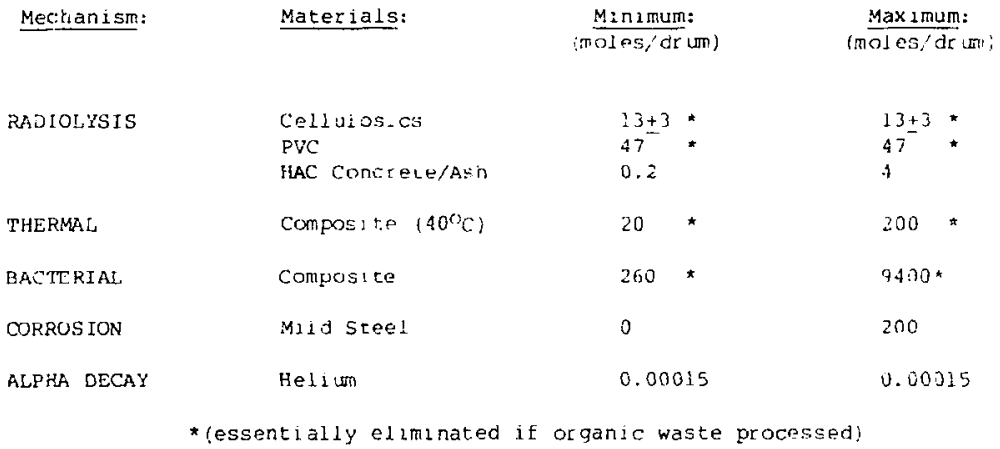

TABLE 3

THEORETICAL GAS GENERATION/DRUM

(ir: air atmosphere)

Zio i 25 un

Polyethylene Drum Liner

$$
\left(\mathrm{C}_{2} \mathrm{H}_{4}\right)_{n}
$$

Cellulosic Waste Matcix

$$
\left(\mathrm{C}_{6} \mathrm{H}_{10} \mathrm{O}_{5}\right)_{\mathrm{n}}
$$

$25 \times 9$

$8.6 \mathrm{~kg}$

$141.4 \mathrm{~kg}$

Total =
$6: 6$ moles $\mathrm{CO}_{\mathrm{X}}$

616 moies $\mathrm{H}_{2}$

5,240 moles $C C_{x}$ 4,360 moles $\mathrm{H}_{2}$

1C, 800 moies; di wT 


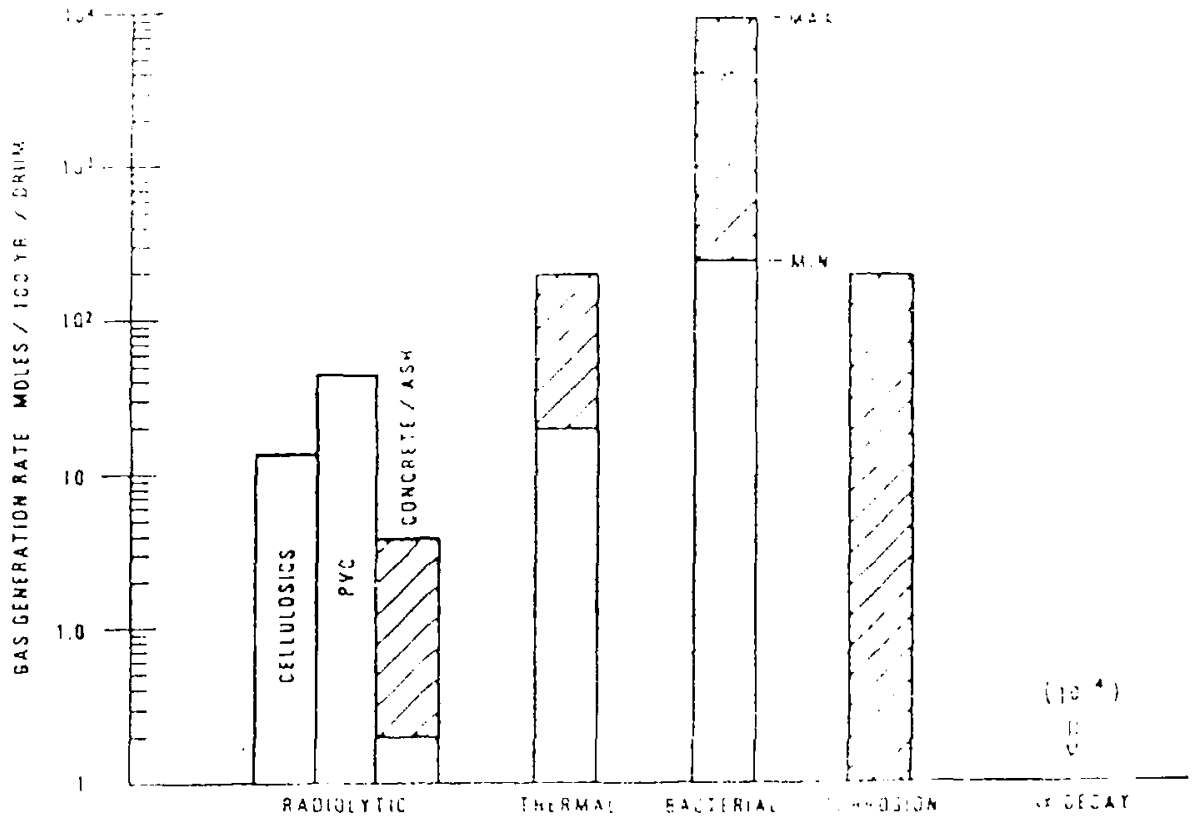

INTERCOMPARATIVE GAS GENERATION RATES 
waste pl scessing of tre organlo matrıx wastes could also esisentially -liminate gas qenaration by thermal and bacterial degradation mechanisms.

The thermal degradation maximum ano minumisn gas values are deperdent in coundary value calculations made for $40^{\circ} \mathrm{C}$ degradation, based on measured vallies ar $70^{\circ} \mathrm{C}$. The tecrease in thermal degradation rates as a function of time has not been determined 10 or ganic wastes in the $40^{\circ}$ to $70^{\circ} \mathrm{C}$ range. The effect of mine catalysts, NaCl and $\mathrm{ke} \mathrm{Cl}_{2}$, on thermal degrastation of collulixics and pilyetnylene at $40^{\circ} \mathrm{C}$ is still bel.7g megsured at LASt. The eifoct of cherma! dewatering of waste forma glich a: TRL Frncess suduges lup to 70 percent by we:ght of water has not teen includra in the maximutenermal gas ralue soown ln pable $\theta$, hut it has been neasured. The bacterial degradation of organic waste matrices provides the geratect potential for gas goneration in a repositiory, hut also nas tir. greatest uncertainty in valif, depending on anvironnental conditions in injlidual druns. The bacterial minimu gas vaiue ls based on measured zeropl : regradation data at $25^{\circ} \mathrm{C}$. The maximus gas val ue, 9400 males/drun, is based on maseured anaerobic gas generation values. However, based on the theoretical thtal amount of gas which coulit be gonerated per drum, 10, 800 moles ITable 31 , the value of 9400 moles deens excrisively high--or overiy optimiatic. The taty of taciurial degradation as a function of time is xi: present!y knowr. It as guati possible that the hacteria would depleze thel source of nutrlents $n$ e drum or organic waste long before 9400 moles of gas $\left(\mathrm{CO}_{2}\right.$, predomi nantly) as e generated. Nonetheless, the total guantity of gas which can be generated by bacterial egegradation appears more signficant than that from any other mechanizm.

Corrosion of the mild steel. used in constructior of 210 l (55 ga1 lon! drums could release a maximum of 200 moles/drum in 100 years if it was 1 nundated with deaerated $\mathrm{NaCl}$ brine at all cimes. This is not very probable. During the period of time when air is still present in the waste storage roum, corrosion will onswne oxyger: and not generate hydrogen. In a dry salt enviroment, with oxygen present, no gaseous corrosion products would be generated.

\section{Additional Work in Progress:}

In order to finalize the necessar'j data base on gas generation from waste degradation, severai topics of investigation ars atill in progress. The topics of greatest sig ificance are listed in Tabla 10. 
TAB LF; 10

\section{MOST SIGNIPICANT GAS GENERATION SIUDIES IN PROGRESS}

1. Deiermine eftects of high pressure on gas generation rates; equilibrium pressuce.

2. Maku tinal raterination of radiolysis rates as a function of several variaties.

3. Deter nine bactertal survival. under salt mine environment.

4. Cbtain further data on bacterial generation, transformation, and corisumption rater.

5. Determine thermal and bacterlal degradation rates as a function of time.

The gas generation quanticies iisted in Table 8 for various mechanisms are not afditjue. Eor instance, if organic waste is degraded to gas by radiolytic and thermal decomposition, the remaining material may not be suitable as further bacterial nutrient. The values in Table 8 are meant to pruvide measured, rasonable limits on quantities of gas to be generated in order to provide input data for consequence assessment studies. Calculations of total gas accumulation in a sealed repository (room) are being coupled with data on gas dissipation via rocksalt permeability. Results of such calculations may be useful for further studies on mine response to gas accumulation and pressure buildup. All of these analyses are now in process, and are reported on elsewhere $(2,37)$. 


\section{REFERENCES}

1. M. A. Molecke, Waste Isolation Pilot Plant Transuranic Wastes Exper imental cnaracterization Progam: Executive Summary, SAND 78-1356, November 1979 .

2. An Interim Summary of Experimental prograns tor the WIPP TRU Waste Acceptance Criteria. Sandia Laboeatories, January 1979, to be published.

3. D. E. Maxwel1, K. K. Wahı, B. Dlal, Sclence Applications, Inc., The Thermomechanical Response of WIPP Repositories, SAI-FR-145, October :978.

4. H. C. Shefelbine, Preliminary Evaluation o: the Charactoristics ot Defense transuranlc Wastes, SAND78-1350, Novenber 1978.

5. S. T. Kosiewlcz, E. A. Bar raclough, and A. Zerwekh, Los Alamos Scientific Laboratory, Quarterly Report. Studjes of rransuranic Waste Under Conditions Expocted an the hasto Isolatzon Pilot Plant, October 1- December 15, 1978, [A-7649-PR, March 1979..

6. S. 'P. Koslewicz, B. L. Barraclough, ano A. Zerwekh, Los Alamos Szientific Laboratory, Quarterly Report. Studies of Transuranic Waste under Conditions Expected in the Waste Isolation Pilot plant, July 1-September 30, 1978, LA-7582-PR, January 1979.

7. 5. Kosiew:C2, A. Zerwekh, and B. Barraclough, Los Alamos Sclentitic baboratory, Fxperimental studies of the Degradation of RAD-wastes for the Sandia Laboratories Waste Isolation Pllot Plant (WIPP), April 1-June 30, 1978, LA-7478-PR, october 1978.

8. S. Kosiew $1 \mathrm{cz}$, A. Zerwekh, and B. Barraclough, Los Alamos Scientific Laboratory, Experimental Studies of the Degradation of RAD-wastes for the Sandia Laboratories waste Isolation Pllct Plant (WIPP), January 1-March 31, 1978, LA-7259-PR, June 1978.

9. S. Xosiewicz, A. Zerwekh, and B. Barraclough, Los Alamos Scientific Laboratory, Experimental Studies of the Degradation of RAD-Wastes for the Sandia Laborator ies Waste I solation Pilot Plant (WIPP), nctober 1-December 1, 1977, [A-7246-PR, MaY 1978.

10. G. R. Waterbury and A. Zerwekh, Office Memor andum, 'TRU Waste Research and Development Program A-412, Annual Report for Period Jan, 1-Dec. 31, 1976, not published.

11. G. R. Waterbury, and A. Zerwekh, office Memorandum, TRU Waste Research and Developilent program A-412, Annual Report for Period Jan. 1-Dec. 31 , 1977, not published.

12. A, zerwekh, Los Alamos Scientific Laboratory, unpublished data, 1973 and 1977 . 
13. N. E. Bitler, fas production lrom Alpha Radiolysis di concrete Contalning TRU Incinerator Ash. Progress Report for April to July, 1978, DPST-78-150-1, February 1979.

14. N. E, yluier, ras Froduction from Radinlysis of Conc ete contalning TRU Inrencratos Ars, Profecse propet for Allgust-November, 1978, DPST-7a-150-2, APE 111979.

15. N. E. Babler, Rarialytic Gas production During l,ong-"'erm Storage of Nuclear Wastes, DP-MS-76-51, papar presented at the 28th Southeastern Regional Meeting of the Anetican Chemical Society, Gatlinburg, TN, octotine 1976.

16. N. E, Ribler, Rariofytic Gass production from Concrete Containing Saraman Rlver Plant Waste, Dp-1464, January 1978.

17. D. E. Caltwall, University ot New Mexico, Microbial Bicgeociemistry of wipl histes, Quarterly Report, June 1-30, 1978, unpublisned.

13. B. J. isachiart, D. E. Calchel:, et al, Potential. Microbial Impact on Iraasuanic Wistes Under Conditions Expected in the waste Isolation Pii ot plant, oclober i-Decembet 2, 1978, LA-7788-PR, May 1979.

19. 3. W. Eralthwate to M. A. Molecke, memo, Thermodyanamlc Calculations ReygrJirg Hydrogen Gas Evolution Due to Corrosion of TRU Waste Contaners, Apr $1121,2978$.

20. J. W. Bra,rhwatte and W. L. Larson to M. A. Molecke, memo, Status Rrport of TRu waste Container Compatability Progran, August 18, 1978.

21. J. W. Bralthwalte to M. A. Molecke, memo, Hydrogen Gas Generation for Corrosion of Loh :- vel Waste Containers, August 9, 1977.

22. J. W. Braithwalte and W. L. Larson to M. A. Molecke, memo, Status Report on \$RU waste Container paint Evaluation, January 10, 1979.

23. T. $N$, Bowmer and " $H$. O'Donnell, Nature of the Side Branches in Low-Denisty Polyethylene: Volatile products from Gamma Radiolysis, Pojyтer, 18, 1032-40, 1977.

24. D. T. Turner, Polyethylene Terephthalate, in The Radiation Chemistry of Macromolecules, II, Malcom Dole, ed., Academic Press, New York, pp. $137-166,197:$.

25. A. Kazanj:an, Radiolytic Gas Generation in Plutonium Contaminated waste Matarials, RFi'-2469, October 1976.

26. J. E. Hoy, Savannan River Laboratory, DPST-78-245, February 1978.

27. K. Grossaint and D. I. Hunter, Rocky Flats Plant, MSL 76-157, unpublished data. 
28. D. [. Hunter, Rocky Flats Plant, MSL 76-399, inpublished data.

29. I. G. Draganis and 7. D. Draganic, The Radiation Chemistry of Wa: ar, Acadent Press, New York, P. 76, 1971.

30. E. J. Murpiy, J. Polymer Sczence, 59, 649, 1962.

31. M. M. Tang, an R. Bacon, Carbonization oí Callulose Fibers--I, Low Temper atuze Pyrolysis, CARBON, 2, 211, 1964.

32. I. V. Vezeshinskil and A. K. Pliaev, Introduction to Radiation Chemistry, Translated from Pusal an, Daniel Davey and Co., New York, $p$. 234,1964 .

33. Mudge et al., Battelle Bacil 10 Northwest Laboratory, waste Treatment and Handling Procosses Anrijal Report, BNWL-1361, September 1974.

34. C. E. Zobell and M. A. Molecke, Survey of Mzcrobial Degradat lon of Asphal ts with Notes on Relatuonihip to Nuclear Waste Managempnt. SAND 78-1371, December 2978.

35. J. A. Cole, Microbia\} Gas Metatolism, Adv. Microbial Physiology, 14 , $1-92,1977$.

36. J. W. Braithwaite and M. A. Molecke, High-Level Waste Canister Corcosion Studies pertinent to Geologic Isolation, SAND 78-2111, December, 1978; also published in NUREG/CP-0005, April 1979.

37. G. F. Barr and D. B. Holdrigge to D.O.E. Wistse Acceptance Criteria Steering Comittee, memo, Current status of Study of: Diffusion of Gas Erom a Repository, November 8, 1978, unpublished. 
DI STRIBUT ION:

U.S. Department of Energy, Headguarters

Office of Nuclear Waste Management.

Wasnington, DC 20545

Eugene F. Beckett, Project Coordinator (WIPP) (1)

colin R. Heath, Director, Division of Waste Isolation (2)

Sheldon Meyers

Raymond $G$. Romatowski

R. Steir

Car! I. - Coole's

U.5. Department of Energy, Albuquerque Operations

P.O. BOY 5:00

Albuguerque, NM 87185

D. T. Schueler, Manager, Wipp Project office (2)

R. Rudolph, Acting Deputy Manager, WIPP project office

3. Dennis, Director, Public AEtairs Division

5. C. Táylor, Cort Division (Eor public Reading Rooms)

U.S. Department of Energy

Car ishad WIPP project of Eice

Room 113, Federal Building

Carlsbad, NM 88220

U.S. Department of Fnergy

cio Battelle

Offlce of Nucleat waste Isolation

$505 \mathrm{king}$ Avenue

Columbus, OH 43201

Jeff 0 . Neff

Hattelle Memorial Institute

Office of Nuclear Waste Isolation

505 king Avenue

Columbus, OH 43201

Neil Carter, General Manager (3)

R. Heineman

Wayne Carbiner

R. Róinson

S. Matthews

A. A. Baver

J. F. Kircher

D. Moak

F. O'Hara

w. Hewi tt

Westinghuuse Electric Corporation

P.O. Box 40039

Albuguerque, NM 87196

R. C. Mairson

D. Hulbert

v. F. Likar

H. H. Irby

A. K. Kuhn, D'Appolonia 


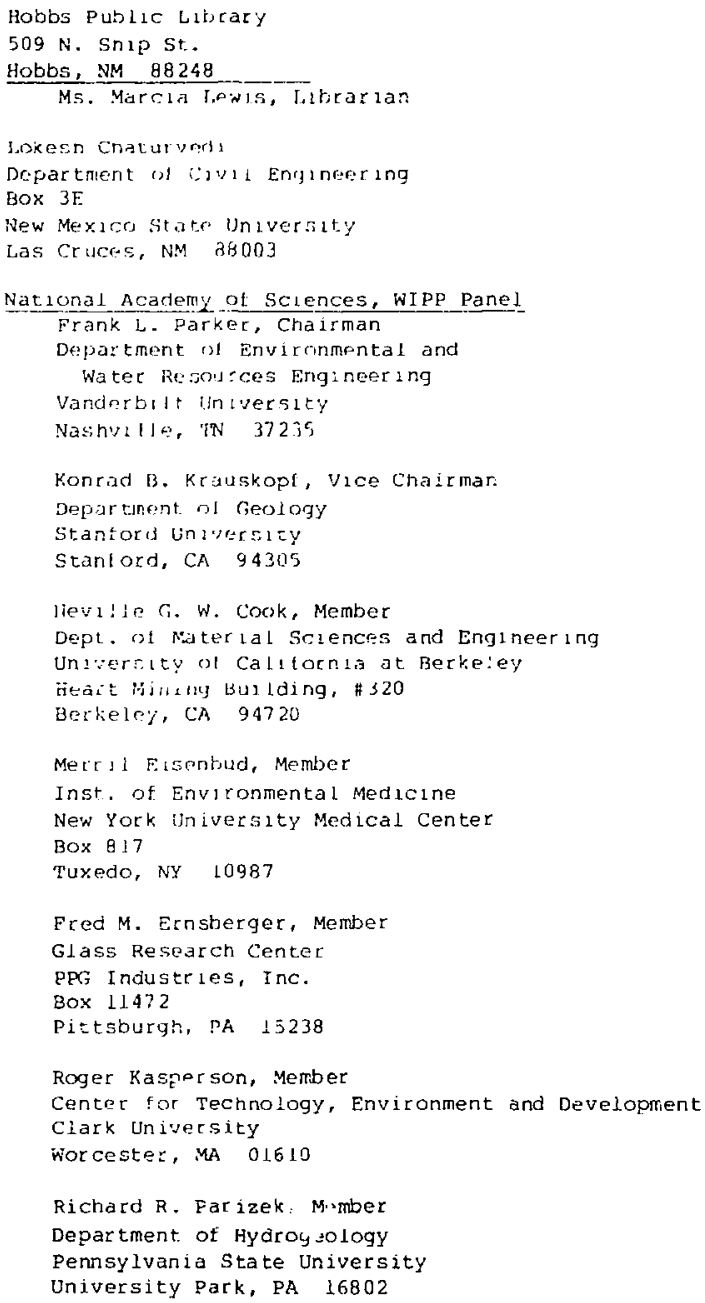




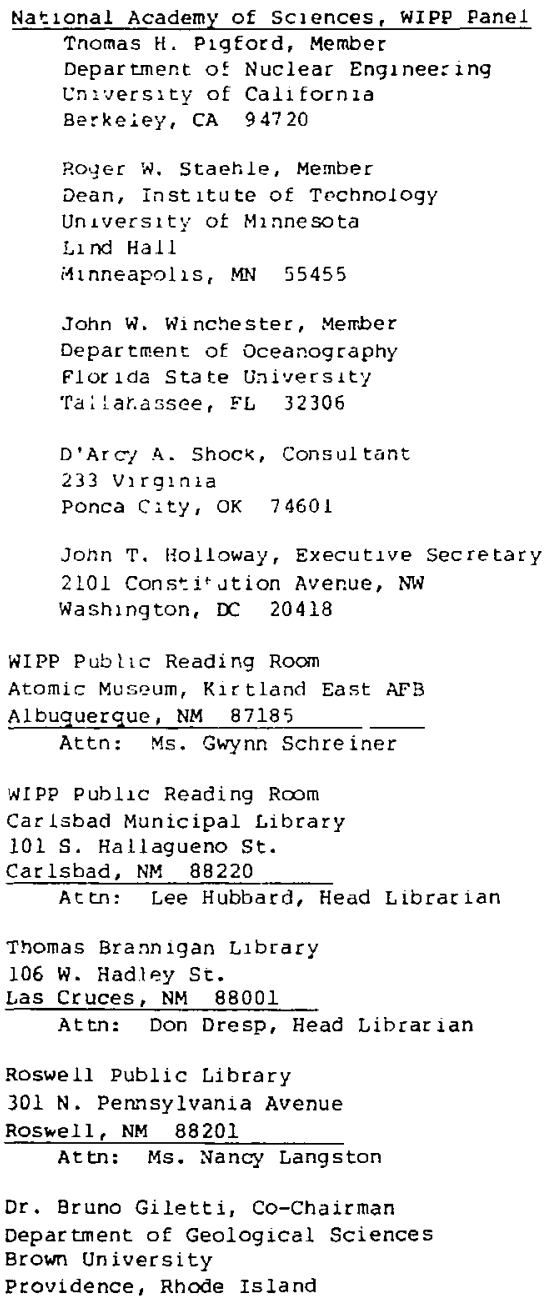




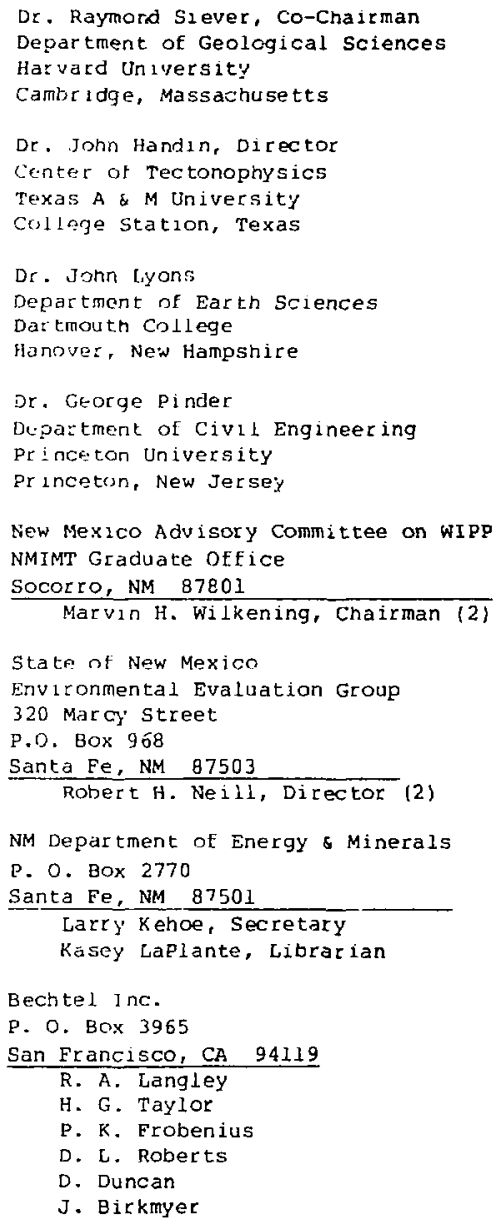

Bechtel Inc.

p. 0. Box 3965

San Francisco, CA 94119
R. A. Langley
H. G. Taylor
P. K. Erobenius
D. L. Roberts
D. Duncan
J. Birkmyer

J. E. Magruder, Sandia Carlsbad Representative 4011 North Canal street

Carlsbad, NM 88220 
Paul w. Levy

Physics Department

Brookhaven Nationa! Laboratory

Associated Universities, Inc.

Upton, Long Island, New York :1973

U. 5. Department of Energy

Idano Operations office

Nuclear Fuel Cycle Division

550 second street

Icaho Falis, ID 83401

‥ M. Nelson

J. Whitsett

R. E. Gerton

U. S. Department of Energy

Richland Operations office

Nuclear Fuel Cycle \& P oduction Division

?. D. BOX 500

Rictiand, WA 99352

1). S. Department of Energy

Savamah River Operations office

Waste Management Project Office

P. O. BOX A

Aiken, SC 29801

J. R. Coveil

D. Fulner

D. E. Large

U. S. Department of Energy

Research \& Tectnical Support Division

P. O. BOX E

Oak Ridge, TN 37830

Rcckwel I International

Rocky Flats Plant

Golden, co $8040 I$

w. S. Bennet

C. E. Wickland

L. Sinith

M. Greinitz

Los Alamos Scientific Labora، $x y$

Los Alanos, NM 87545

Attn: B. J. Barnhart. H-9 (1):-

T. K. Keenan, $\mathbf{H}-7$

D. F. Petersen, H-DO

G. R. Waterbury, CMB-1

A. Zerwekh, CMB-l

S. Kosiewicz, CMB-1 
Oak Ridge National Laboratory

Box $y$

Oak Ridge, TN 37830

Attn: R. E. Blanko

L. R. Dol?

K. Half

i. G. Moore

E. T. Wupont de Nemuurs Company

Suvannab Ruver Laboratory

Azken, SC 29801

E. L. Albenisius

N. E. Blbler

J. R. Wlley

Argunne Natıona: Laboratory

9700 South Cass Arenue

Argorine, IL 60439

S. Fried

A. M. Frledman

L. Jardine

M. Steindier

Mound Research Corporation

Mound Laboratory

Miamisburg, $\mathrm{OH}$

45342

J. W. Doty

K. V. Gilbert

Brookhaven National faboratory

Department of Applied sciences

upton, NY 11973

P. Colombo

R. M. Nielson

Univeraity of New Mexico

Binlogy Department

Albuquerque, iNM 87131

D. E. Caldwel!.

Battelie Pacific Northwest Laborator ies

Battelle Boulevara

Richland, WA 99352

D. J. Bradley

R. I. Serne

C. R. palmer

C. E. ZOBel $1, \mathrm{~A}-002$

Scripps Institute of Oceanography

University of California, San Diego

La Jolla, Ch 92093 
U. S. Department of Energy

Division of Waste Products

Mali Stop B-107

washington, DC 20545

G. H. Daly

J. E. Dieckthoner

\section{Sandia Internal:}

1100 C. D. Bruyies

1110 J. D. Kennedy

1130 H. E. Viney

1520 T. L. Pace

3310 W. D. Burnett

3313 A. L. Stanley

$3141 \mathrm{~T}$. L. Werner (5)

3151 W. L. Gazner, Eרr: DOE/TIC (Unllinited Reiease) (3)

3154-3 R. P. Campbel1, For: DOE/TIC (25)

4500 I. H. Beckner

4510 W. D. Weart

4511 W. D. Weart (Acting)

4511 G. E. Barr

4512 T. O. Hunter (5)

4512 C. L. Christensen

4512 D. R. Fortney

4512 M. A. Molecke (15)

4512 A. R. Sattler

$4512 \mathrm{~J} . \mathrm{R}$. Wayland

4514 M. L. Mercitt

4514 F. W. Binghan

4540 M. L. Kramm

4541 L. W. Scully

4541 P. D. O'Brien

4541 H. C. Shefelbine

4541 W. E. Wowak

4542 Sandia wIpp Central Files (2)

4530 R. W. Lynch

4537 L. D. Tylet

4538 R. C. Lincoln

5511 D. F. McVey

5521 S. W. KeY

$5530 \omega$. Herrmann

5531 L. D. Bertholf

5532 B. M. Butcher

5812 C. J. Northrup

5812 R. G. Dosch

5812 B. T. Kenna

5812 E. J. Nowak

5831 N. J. Magnani

5831 J. W. Braithwaite

8266 E. A. Aas (2) 